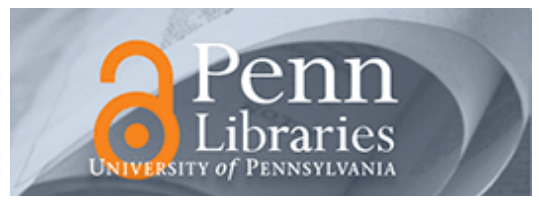

University of Pennsylvania ScholarlyCommons

\title{
Do Firms Adjust Their Timely Loss Recognition in Response to Changes in the Banking Industry?
}

Todd A. Gormley

University of Pennsylvania

Bong Hwan Kim

University of Pennsylvania

Xiumin Martin

Follow this and additional works at: https://repository.upenn.edu/fnce_papers

Part of the Finance Commons, and the Finance and Financial Management Commons

\section{Recommended Citation}

Gormley, T. A., Kim, B. H., \& Martin, X. (2012). Do Firms Adjust Their Timely Loss Recognition in Response to Changes in the Banking Industry?. Journal of Accounting Research, 50 (1), 159-196. http://dx.doi.org/ 10.1111/j.1475-679X.2011.00429.x

This paper is posted at ScholarlyCommons. https://repository.upenn.edu/fnce_papers/312

For more information, please contact repository@pobox.upenn.edu. 


\title{
Do Firms Adjust Their Timely Loss Recognition in Response to Changes in the Banking Industry?
}

\author{
Abstract \\ This paper investigates the impact of changes in the banking sector on firms' timely recognition of \\ economic losses. In particular, we focus on the entry of foreign banks into India during the 1990s, which \\ likely causes an exogenous increase in lender demand for timely loss recognition. Analyzing variation in \\ both the timing and the location of the new foreign banks' entries, we find that foreign bank entry is \\ associated with more timely loss recognition and this increase is positively related to a firm's subsequent \\ debt levels. The change appears driven by a shift in firms' incentives to supply additional information to \\ lenders and lenders seem to value this information. The increase in timely loss recognition is also \\ concentrated among firms more dependent on external financing: private firms, smaller firms, and \\ nongroup firms. Overall, our evidence suggests that a firm's accounting choices respond to changes in the \\ banking industry.

\section{Disciplines} \\ Finance | Finance and Financial Management
}




\title{
Do Firms Adjust Their Timely Loss Recognition in Response to Changes in the Banking Industry?*
}

\author{
Todd A. Gormley ${ }^{\dagger}$, Bong Hwan Kim${ }^{\ddagger}$ and Xiumin Martin ${ }^{\S}$
}

Current version: July 13, 2011

\begin{abstract}
This paper investigates the impact of changes in the banking sector on firms' timely recognition of economic losses. In particular, we focus on the entry of foreign banks into India during the 1990s, which likely causes an exogenous increase in lender demand for timely loss recognition. Analyzing variation in both the timing and the location of the new foreign banks' entries, we find that foreign bank entry is associated with more timely loss recognition and this increase is positively related to a firm's subsequent debt levels. The change appears driven by a shift in firms' incentives to supply additional information to lenders and lenders seem to value this information. The increase in timely loss recognition is also concentrated among firms more dependent on external financing: private firms, smaller firms, and non-group firms. Overall, our evidence suggests that a firm's accounting choices respond to changes in the banking industry.
\end{abstract}

Keywords: Bank Entry, Information, Timely Loss Recognition, India JEL Classification: D82, G21, O16, M41

\footnotetext{
${ }^{*}$ We would like to thank the editor, Philip Berger, the anonymous referee, Anne Beatty (discussant), Mark Bradshaw (discussant), Rich Frankel, Radhakrishnan Gopalan, Bob Holthausen, Christian Leuz, Tara Rice (discussant), Cathy Schrand, and seminar participants at the American Finance Association 2010 annual meeting, NBER Corporate Finance Program Fall 2009 Meeting, Financial Intermediation Research Society 2009 Annual Meeting, FARS Mid-Year Meeting 2010, 2010 Global Issues in Accounting Conference, University of Chicago (Booth), Washington University in St. Louis (Olin), and the Wharton junior faculty lunch. Bong Hwan Kim acknowledges financial support from the Center for Research in Economics and Strategy (CRES), in the Olin Business School, Washington University in St. Louis. The Prowess data set used in this paper was provided by the IMF through their visiting scholars program. The analysis and conclusions in this paper, however, are our own and do not necessarily represent those of the IMF or IMF Policy. All remaining errors and omissions are our own.

${ }^{\dagger}$ The Wharton School, University of Pennsylvania, 3620 Locust Walk, Suite 2400, Philadelphia, PA, 19104. Phone: (215) 746-0496. Fax: (215) 898-6200. E-mail: tgormley@wharton.upenn.edu

${ }^{\ddagger}$ Kogod School of Business, American University, E-mail: bkim@american.edu

$\S$ Olin Business School, Washington University in St. Louis, Campus Box 1133, One Brookings Drive, St. Louis, MO 63130. Phone: (314) 935-6331. Fax: (314) 935-6359. E-mail: xmartin@wustl.edu
} 


\title{
Do Firms Adjust Their Timely Loss Recognition in Response to Changes in the Banking Industry?
}

\begin{abstract}
This paper investigates the impact of changes in the banking sector on firms' timely recognition of economic losses. In particular, we focus on the entry of foreign banks into India during the 1990s, which likely causes an exogenous increase in lender demand for timely loss recognition. Analyzing variation in both the timing and the location of the new foreign banks' entries, we find that foreign bank entry is associated with more timely loss recognition and this increase is positively related to a firm's subsequent debt levels. The change appears driven by a shift in firms' incentives to supply additional information to lenders and lenders seem to value this information. The increase in timely loss recognition is also concentrated among firms more dependent on external financing: private firms, smaller firms, and non-group firms. Overall, our evidence suggests that a firm's accounting choices respond to changes in the banking industry.
\end{abstract}

Keywords: Bank Entry, Information, Timely Loss Recognition, India JEL Classification: D82, G21, O16, M41 
This paper investigates whether firms attempt to make their accounting statements more conservative in response to the changes in the banking industry. Such a response might arise since firms' financial statements are used extensively by banks and other creditors in making lending decisions and monitoring borrowers. One aspect of information that is of high value to lenders is a firm's timely loss recognition (Watts and Zimmerman, 1986; Basu, 1997; Watts, 2003a). Evidence suggests that timely loss recognition is related to a firm's cost of credit in the U.S. (Ahmed, Billings, Morton, and Harris, 2002; Wittenberg-Moerman, 2008; Zhang, 2008; and Nikolaev, 2010) and the development of credit markets internationally (Ball, Robin, and Wu, 2003; Ball, Robin, and Sadka, 2008). If changes in the banking sector affect lenders' demand for conservatism, such as the arrival of new lenders that rely more heavily on information contained in firms' financial statements, firms may respond by changing their accounting practices. $^{1}$

While the evidence suggests that firms are likely to adjust their accounting policies in response to changes in the banking sector, there is little direct evidence of this occurring. Empirical evidence is sparse in part because of the difficulty of isolating a change in the banking sector that affects the costs and benefits of being conservative but is not related to other factors that may also affect reporting policies. Our paper overcomes this challenge by exploiting an exogenous increase in the benefit of being conservative caused by the entry of foreign banks into India during the 1990s.

The entry of foreign banks into India is likely to increase the banking sector's

\footnotetext{
${ }^{1}$ Throughout the paper we use the term conservatism and timely loss recognition interchangeably. Timely loss recognition refers to the timely incorporation of economic losses into accounting earnings (Basu, 1997; Watts, 2003a) and it is also termed as asymmetric timeliness or conditional conservatism. Ball and Shivakumar (2005, pp. 88-92) explain the role of conditional conservatism in efficient contracting, and contrast it with unconditional conservatism which is argued to have no positive effect on efficient contracting.
} 
demand for conservative financial statements in three unique ways. First, foreign banks may be less able to acquire soft information about local firms, leading them to place a greater emphasis on the information contained within firms' financial statements (Stein, 2002). This may be particularly true when foreign banks are from developed countries where financial statements are commonly used to screen and monitor borrowers (Bushman and Piotroski, 2006). Second, foreign banks' tendency to 'cream-skim' the larger, more profitable firms in developing countries (Dell'Arricia and Marquez, 2004; Gormley, 2007; Sengupta, 2007; Detragiache, Gupta, and Tressal, 2008) may increase domestic lenders' emphasis on conservative financial statements. Because creamskimming by foreign banks lowers the average quality of borrowers seeking domestic bank loans, domestic banks' incentive to screen and monitor loans more intensely, which could include looking for conservative financial statements, might increase (Gormley, 2007). ${ }^{2}$ Third, domestic lenders in developing countries, which may be initially less sophisticated in their lending skills, may adopt the 'best practices' of foreign banks, further increasing the importance of a firm's accounting statements in the lending process (Lensink and Hermes, 2004). Each of these changes in the banking sector is likely to increase firms' incentives to provide more conservative financial statements.

We assess whether firms adjust their timely recognition of losses in response to changes in the banking industry using an exogenous regulatory change. In particular, we make use of the staggered entry of foreign banks into India following the country's 1994 commitment to the World Trade Organization (WTO). Some districts of India received a foreign bank branch as early as 1994, while others did not receive such a branch until

\footnotetext{
${ }^{2}$ In addition to scrutinizing a borrower's hard information more closely, it is also possible that domestic lenders improve the effectiveness of their ex ante screening and ex post monitoring by collecting more soft information about each borrower. The two approaches are not mutually exclusive.
} 
2001, and as of today, many districts have yet to receive a foreign bank. Matching this information to a large panel data set of firms' audited financial statements, we compare changes in timely loss recognition between domestic firms located geographically near the new foreign banks and domestic firms located further from the new banks. The variation both in the timing of the new foreign banks' entries and in their location within the country reduces potential confounding effects that might arise from other countrywide changes in firms' accounting standards. Such country-wide changes would affect all firms in India and therefore are unlikely to explain differential changes in accounting choices for firms located geographically near foreign banks versus those that are not.

Another advantage to analyzing changes in timely loss recognition and changes in the banking sector in India is our ability to obtain detailed firm-level data for both public and private Indian firms. By using firm-level data, we can test for a heterogeneous effect across firms as well as control for any differences in the types of firms located in areas with a new foreign bank. The data on private firms, which are potentially more sensitive to changes in local lending markets, also allow us to analyze the reporting policies for firms that are generally not represented in most studies.

To measure a firm's timely recognition of economic losses, we follow the research design by Ball and Shivakumar (2005) and apply an accrual-cash flow nonlinear regression technique. Since this measure only relies on the information in firms' historical financial statements, we are able to calculate it for both public and private firms in India. This is particularly important since the benefit of conservative financial statements is likely greater for private firms after foreign bank entry.

Using the aforementioned framework, we find evidence that firms' accounting choices are associated with changes in the banking industry. The overall level of timely 
loss recognition increases for firms located in the vicinity of new foreign banks, and the timing of this increase coincides with foreign bank entry into each district. The increases in timely loss recognition are also concentrated among debt-dependent firms with the strongest incentives to adjust their accounting procedures so as to reduce information asymmetries and alleviate financing constraints. More specifically, we find that smaller, non-group, and private firms, particularly private firms with greater dependence on external financing, increase their timely loss recognition the most. The findings are robust to the use of different samples, time periods, and control variables. In addition to the increase in timely loss recognition, we also find corroborating evidence of an increase in write-offs of fixed assets and bad debt expenses. These changes are consistent with firms increasing their conservatism in response to changes in the banking sector.

The evidence also indicates that lenders value this change in accounting conservatism. Within districts that experience a foreign bank entry, we find the largest increases in timely loss recognition occur, on average, among firms that maintain or increase their level of borrowings following foreign bank entry, whereas firms that experience declines in their debt levels exhibit no average increase.

Our findings add to the growing evidence that the benefits and costs of providing high quality financial information can cause shifts in accounting choices. For example, Willenborg (1999) and Leone, Rock, and Willenborg (2007) find that firms respond to changes in the costs and benefits of providing information to equity holders in event of an IPO; Zhang (2009) finds that borrowers with greater accounting conservatism are able to borrow at lower cost; and Minnis (2011) finds that private firms undergo voluntary audits in order to improve their access to the debt market. Our paper demonstrates that firms also adapt their accounting policies, timely loss recognition in particular, to changes in 
the banking industry. To the authors' knowledge, this dynamic connection between conservatism and banking sector characteristics has not been documented before.

Our findings also reinforce the importance of timely loss recognition and its role in the debt contracting process (Ahmed, Billings, Morton, and Harris, 2002; Beatty, Weber, and Yu, 2008; Guay, 2008; Wittenberg-Moerman, 2008; Zhang, 2008). Rather than analyze the importance of timely loss recognition in a static credit market, however, our paper uses an exogenous regulatory change to test whether changes in the banking industry are correlated to changes in firms' accounting choices. We also explore how these changes in accounting choices vary across firms, and whether these changes affect firms' credit access. There is little existing evidence on the relation between financial reporting and access to debt financing (Armstrong, Guay, and Weber, 2010).

Our paper also provides supporting evidence to the argument of Ball (2001) and Kothari (2001) that institutional mechanisms are important in shaping a country's accounting choices. Previous research has explored the relation between accounting practices and legal institutions (Ball, Kothari, and Robin, 2000), equity market development and investor rights (Leuz, Nanda, and Wysocki, 2003), tax systems (Ali and Hwang, 2000; Guenther and Young, 2000) and political connections (Chaney, Faccio, and Parsley, 2009). Our paper suggests that banking sector characteristics may also be important in shaping a country's accounting practices over time.

Finally, this paper is related to the literature that studies the relations between foreign bank entry, domestic bank performance, interest rates, and firms' debt usage. ${ }^{3}$

\footnotetext{
${ }^{3}$ Claessens, Demirguc-Kunt, and Huizinga (2001) uncover evidence that foreign bank entry is associated with lower profit margins among domestic banks, while Berger, Klapper, and Udell (2001), Haber and Musacchio (2004), and Mian (2006) provide evidence that foreign banks tend to finance only larger, more established firms. Clarke, Cull, and Martinez Peria (2006) find that entrepreneurs in countries with high levels of foreign bank ownership perceive interest rates and access to loans as smaller constraints to their operations. Detragiache, Gupta, and Tressal (2008) and Gormley (2010) find that foreign ownership is
} 
This paper compliments this literature by analyzing the changes in firms' accounting practices following foreign bank entry into a market where firms seemingly face very few incentives to produce informative financial statements. Our evidence suggests that in this type of environment, firms improve the conservatism of their financial statements following the entry of lenders that place greater emphasis on these statements. The observed increase in conservatism is also consistent with theories suggesting that financial sector competition may affect the importance of firms' informationalopaqueness (Dell'Arricia and Marquez, 2004; Gormley, 2007; Sengupta, 2007) and supports the argument that firms' incentive to provide conservative financial statements is important (Ball, Robin, and Wu, 2003; Ball, Robin, and Sadka, 2008).

The remainder of the paper proceeds as follows. Section 1 provides a review of India's policy change. Section 2 develops testable hypotheses. Section 3 describes the data and research design. Section 4 presents empirical results, and Section 5 presents robustness tests. Section 6 concludes.

\section{Description of banking sector changes in India}

Prior to 1991, India's economy and financial system were heavily regulated and dominated by the public sector. Following a balance of payments crisis in 1991, however, a number of structural reforms were implemented that greatly deregulated many economic activities. In November 1991, a broad financial reform agenda was established in India by the Committee on the Financial System (CFS). One of the committee's

\footnotetext{
negatively related to aggregate and firm-level measures of debt-usage, while within Eastern European countries, Giannetti, and Ongena (2009a) find the share of foreign lending to be positively related to firmlevel sales and overall debt usage, particularly for larger firms. Giannetti and Ongena (2009b) also find that foreign bank entry may make bank relationships more stable and enhance financial access. Berger, Klapper, Peria, and Zaidi (2008) find suggestive evidence that firms choose to have multiple bank relationships as an insurance against the 'fragility' of foreign bank relationships.
} 
recommendations to meet this goal was to introduce greater competition into the banking system by allowing more foreign banks to enter India.

However, no significant action was taken by the Government of India regarding the CFS recommendation on foreign banks until April 1994 when the government agreed to allow for an expansion of foreign banks under the General Agreement on Trades in Services (GATS). In the initial GATS agreement, India committed to issue five additional branch licenses to both new and existing foreign banks each year. In a subsequent supplemental agreement in July 1995, India increased the limit to eight licenses per year, and in February 1998, the limit was increased to 12. While there were no restrictions on where foreign banks could choose to establish new branches, the expansion of foreign banks in India was allowed by de novo branches only. ${ }^{4}$

In the years preceding the signing of the GATS agreement, very few licenses for new foreign bank branches were granted, and the presence of foreign banks in India was limited. On March 31, 1994 there were 24 foreign banks with 156 branches in India. Most of these banks, however, had begun operations before India's first nationalization of private banks in April 1969, and only seven new branches had opened since 1990. Moreover, most of India's 575 districts did not have a foreign bank, as roughly 75 percent of these foreign bank branches were concentrated in districts encompassing India's three largest cities: Delhi, Mumbai, and Kolkata.

In the eight years following the acceptance of GATS, however, 17 new foreign banks and 89 new foreign bank branches were opened in India bringing the total number

\footnotetext{
${ }^{4}$ Foreign banks were not allowed to own controlling stakes in domestic banks, and foreign banks wishing to establish new branches needed to seek Reserve Bank of India approval, as do all banks under Section 23 of the Banking Regulation Act, 1949. Requests for new branches are evaluated on the "merits of each case and taking into consideration overall financial position of the bank, quality of its management, efficacy of the internal control system, profitability, and other relevant factors". See "Master Circular on Branch Licensing,” DBOD.No. BL.BC. 5/22.01.001/2004, Reserve Bank of India, Mumbai, pp. 4.
} 
foreign banks to 41 with 212 branches as of March 2002. ${ }^{5}$ The expansion of foreign banks also increased their representation outside of India's most populous cities, as the number of districts with a foreign bank increased from 18 to 26 , and foreign banks' share of total long-term loans increased as well. In March 1994, foreign banks accounted for five percent of all outstanding long-term loans, but with their expansion of branches, their share of long-term loans increased and averaged roughly eight percent from 1996 to 1998, and 10 percent from 1999 to 2001. Moreover, foreign bank entry was sizeable in the eight districts receiving their first foreign bank. By 2003, foreign banks accounted for roughly 5.5 percent of long-term loans in these districts.

While foreign banks' entry, as measured by captured market share, was relatively small, it had a significant impact on local credit markets and firms. Gormley (2010) finds that while bank borrowings increased for large, profitable firms following foreign bank entry into India, the average domestic firm located in the vicinity of a new foreign bank experienced a drop in bank borrowings. These declines were larger on average among firms generally considered more informationally-opaque, such as smaller firms and firms with fewer tangible assets. The drop in credit also appears to adversely affect the performance of smaller firms with greater dependence on external financing. The experience of India is consistent with the cross-country evidence of Detragiache, Gupta, and Tressal (2008), which also finds evidence that foreign bank entry is associated with reduced bank credit among informationally-opaque firms.

The reduced use of debt for many firms in India following foreign bank entry might suggest that the benefit of providing more conservative financial statements to

\footnotetext{
${ }^{5} 33$ foreign bank branches closed during this time period, so the net change was only 56.17 of these closures were from ANZ Grindlays Bank Ltd. and five from Standard Chartered Bank in 1998 and 1999.
} 
lenders increased. We now turn to exploring why this might occur and how this might vary across firms.

\section{Hypotheses development}

In making lending decisions, banks face ex-ante information asymmetry and expost moral hazard problems. To overcome these frictions, banks can adopt stringent screening standards (Ramakrishnan and Thakor, 1984) and/or monitor borrowers (Diamond, 1984). Each requires information about the creditworthiness of borrowers. While some information on credit quality can be obtained from borrowers (soft information), credit agencies, suppliers, and customers of a firm, a large share of the information used by lenders will be contained in the firms' financial statements.

One particular accounting metric that is valuable to lenders is the timely accounting recognition of economic losses (Watts and Zimmerman, 1986; Ahmed, Billings, Morton, and Harris, 2002; Watts, 2003a, 2003b; Beatty, Weber, and Yu, 2008). Because of lenders' asymmetric payoff from firms' net assets (lenders incur a loss when the net assets of borrower are below the principal but are not compensated when the net assets exceed the principal), lenders are concerned with the lower bound of a borrower's net asset value. Timely loss recognition ensures, however, that expected losses are reflected in the financial statements earlier and that the borrowers' true net asset value is not overstated (Watts, 2003a). This lower bound is informative to the lenders in making lending decisions and in specifying financial covenants. ${ }^{6}$ Timely loss recognition also increases the effectiveness of ex-post monitoring because it better informs lenders about a

\footnotetext{
${ }^{6}$ There is evidence that banks in India use covenants to monitor borrowers. For example, on February 11, 2001, the Financial Times reported that Indian banks "have been asked by the Reserve Bank of India to make bill finance one of the covenants for sanction of working capital credit limits".
} 
borrower's ability to repay, and the decreased reported earnings help constrain dividends, thus alleviating the ex-post moral hazard problems (Watts and Zimmerman, 1986).

Several studies find evidence consistent with timely loss recognition having a positive effect on debt contract efficiency. Ahmed, Billings, Morton, and Harris (2002) find evidence that timely loss recognition plays an important role in mitigating bondholder and shareholder conflicts over dividend policy and in reducing firms' borrowing costs. Zhang (2008) shows that timely loss recognition benefits lenders through a timely signaling of default risk, and benefits borrowers through a lower cost of debt. Beatty, Weber and $\mathrm{Yu}(2008)$ find evidence that debt covenants and timely loss recognition are complementary in meeting lenders' demand, and Nikolaev (2010) finds that timely loss recognition compliments the use of covenants to address agency costs.

On the other hand, timely loss recognition can be costly for firms. Earlier recognition of losses lowers stated earnings, which may reduce outsiders' valuation of the company, constrain dividend payment to shareholders, adversely affect managerial compensation, and potentially lower firm's ability to obtain external credit in the shortrun (Ahmed, Billings, Morton, and Harris, 2002). Firms also violate debt covenants earlier when they are timely in their recognition of losses (Zhang, 2008), and such violations can be costly for firms (Roberts and Sufi, 2009). Timely loss recognition may also reduce a manager's private benefits, particularly in countries with weak investor protections (Leuz, Nanda, and Wysocki, 2003).

Given these costs, firms face a trade-off when choosing how timely to recognize economic losses. Holding all else equal, loss recognition is expected to be timelier when the potential benefits of doing so increase, and vice versa, loss recognition should be less 
timely when the potential costs increase.

The entry of foreign banks into India is likely to increase the banking sector's demand for conservative financial statements in three unique ways. First, foreign banks may be less able to acquire soft information about local firms, leading them to place a greater emphasis on the information contained within firms' financial statements (Stein, 2002). This may be particularly true when foreign banks are from developed countries where financial statements are commonly used to screen and monitor borrowers (Bushman and Piotroski, 2006). Second, foreign banks' potential to 'cream-skim' the larger, more profitable firms in developing countries (Dell'Arricia and Marquez, 2004; Gormley, 2007; Sengupta, 2007; Detragiache, Gupta, and Tressal, 2008) may also increase domestic lenders' emphasis on conservative financial statements. ${ }^{7}$ Because cream-skimming by foreign banks lowers the average quality of borrowers seeking domestic bank loans, domestic banks' incentive to screen loans more intensely, which could include looking for conservative financial statements, might increase (Gormley, 2007). Third, domestic lenders in developing countries, which may be initially less sophisticated in their lending skills, may adopt the 'best practices' of foreign banks, further increasing the importance of a firm's accounting statements in the lending process (Lensink and Hermes, 2004). Each of these changes in the banking sector is likely to increase firms' incentives to provide more conservative financial statements.

The potential change in lenders' demand for conservative financial reports following foreign bank entry provides firms with an incentive to improve the

\footnotetext{
${ }^{7}$ A general theme of these theoretical models is that foreign banks enjoy a lower marginal cost of capital relative to domestic banks but have a high cost of acquiring soft information. This comparative advantage leads to a segmented market where foreign banks tend to finance the largest, most profitable firms either because the loans are larger (allowing foreign banks to take advantage of their lower marginal cost of capital) or because the acquisition of soft information is not necessary for these firms.
} 
conservatism of their financial statements. Since timely loss recognition may help accomplish this, we conjecture it will increase when foreign bank entry occurs. Therefore, our first hypothesis is stated as follows:

HYPOTHESIS 1 (H1): The level of timely loss recognition will increase in districts where foreign bank entry occurs.

A rejection of this hypothesis would indicate that foreign bank entry has no impact on timely loss recognition. This might occur if foreign bank entry does not increase the benefit of firms providing more conservative financial statements, or if lenders do not value this particular change in a firm's reporting policy because there exist alternative mechanisms to accommodate lenders' needs.

The increased benefit of having conservative financial statements following foreign bank entry is also likely to vary across firms. Firms that are dependent on external financing, particularly informationally-opaque firms that rely heavily on bank loans, may find it more beneficial to increase conservatism if doing so can increase the odds of maintaining credit access in a financial market with foreign lenders. As a result, small and private firms, which are typically more informationally-opaque and dependent on bank financing, may have the greatest incentive to adjust accounting policies following foreign bank entry. ${ }^{8}$ Non-group firms may also have a greater incentive to improve the conservatism of their financial statements if they are more likely to depend on external financing. Our second hypothesis is stated as follows:

\footnotetext{
${ }^{8}$ Theory also suggests that soft-information loans are more likely to decline after foreign bank entry (Gormley, 2007; Detragiache, Gupta, and Tressal, 2008). Given this, informationally-opaque firms, which rely more heavily on soft-information lending, may also have a greater incentive to improve conservatism so as to avoid an adverse drop in their credit access after foreign bank entry.
} 
HYPOTHESIS 2 (H2): The change in timely loss recognition will be more pronounced among firms with greater external financing dependence, such as small, private, and non-group firms.

Finally, if increased timely loss recognition reduces the risk born by lenders in assessing firms' creditworthiness, we expect lenders to reward firms who increase their timely loss recognition by granting relatively more credit to these firms. Therefore, our third hypothesis is stated as follows:

HYPOTHESIS 3 (H3): The change in timely loss recognition after foreign bank entry will be positively associated with firms' access to credit.

\section{Data and research design}

\subsection{Data}

The data set used to identify the location and opening date for each foreign bank in India is the Directory of Bank Offices published by the Reserve Bank of India. Providing the location, name, opening date, and closing date for every bank office in India, the data are used to construct a complete annual directory of all banks in India from 1988 to 2002 .

With these data, it is possible to map out the timing and location of arrival for the new foreign banks. Table 1 shows the number of foreign banks by district and year from 1990 to 2002. In the top half of the table are the 18 districts that already had a foreign bank before 1991. These include the three districts with very large metropolitan centers: Delhi, Greater Mumbai, and Kolkata. In the bottom half are the eight districts that received their first foreign bank during the 1990s. As can be quickly seen, the overall increase in foreign bank branches largely coincides with the signing of the GATS in 
1994, but the actual timing of entry across these eight districts is staggered across years.

The district location of new foreign banks is mapped in Figure 1, which highlights the eight districts that received their first foreign bank between 1991 and 2002. The eight districts are relatively dispersed across India, spanning seven of India’s 35 states. ${ }^{9}$

[Insert Table 1 here]

[Insert Figure 1 here]

The bank location data are matched up to the Prowess data set compiled by the Centre for Monitoring Indian Economy (CMIE). Prowess is a panel data set of firms from 1988 to 2002 where both listed and unlisted publicly limited Indian and foreign firms with assets plus sales greater than 40 million Rupees (approx. \$900,000) are included in the data set. ${ }^{10}$ The data set provides the annual financial and accounting data of each firm along with descriptive variables including the ownership, year of incorporation, and registered address. Using each firm's address, it is possible to track their financial status at the district level and to merge this data to the district location of the new foreign banks in India. To ensure a comparable sample of control firms, we exclude firm-year observations for firms located in the districts that already have a foreign bank prior to liberalization. Because these districts experience additional entry after liberalization and the existing foreign banks may also be expanding operations, the inclusion of these districts as a control sample for the eight districts receiving their first

\footnotetext{
${ }^{9}$ Citibank and HSBC were responsible for half of the new foreign bank branches in the eight districts. Other banks opening branches in these districts were ABN AMRO, American Express Bank Ltd., ANZ Grindlays, BNP Paribas, Crédit Lyonnais, Deutsche Bank (Asia), Société Générale, and Standard Chartered. Each had pre-existing branches elsewhere in India at the time of entry in the eight districts.

${ }^{10} \mathrm{CMIE}$ compiles the financial data using the audited annual accounts that all registered companies in India must submit to the Registrar of Companies. The cutoff level of firm size in the Prowess data set seems to be an arbitrary point chosen to limit the size of the database.
} 
foreign bank would be problematic. ${ }^{11}$ In addition, firms in these districts are likely different in many ways because of prior foreign bank entry. ${ }^{12}$ Our final sample consists of 20,434 firm-year observations for 2,547 unique firms over the period 1988-2002. ${ }^{13}$

While foreign banks only entered eight new Indian districts after liberalization, the financial data provided by Prowess indicate that a large number of Indian firms were likely affected by this entry. Within our sample, these eight districts account for 25 percent of the observed firms and 24 percent of total sales in 1992. These high numbers reflect foreign banks' tendency to locate in heavily populated districts.

\subsection{Measuring timely loss recognition}

Following Ball and Shivakumar (2005), we measure timely loss recognition using a non-linear relation between operating cash flows and accruals. The model is as follows:

$$
A C C_{i t}=\beta_{1} D C F O_{i t}+\beta_{2} C F O_{i t}+\beta_{3} D C F O_{i t} \times C F O_{i t}+\varepsilon_{i t}
$$

The dependent variable $A C C_{i t}$ is accruals computed as $\left[\left(\Delta C A_{i t}-\Delta C a s h_{i t}\right)-\right.$ $\left.\left(\Delta C L_{i t}-\triangle S T D_{i t}\right)-D E P_{i t}\right]$ scaled by total assets for firm $i$ in year $t$, where $\triangle C A$ is the change in current assets, $\triangle C a s h$ is the change in cash and bank balances, $\triangle C L$ is the change in current liabilities, $\triangle S T D$ is the change in short term debt, and $D E P$ is depreciation expense. ${ }^{14} \mathrm{CFO}$ represents the operating cash flows (scaled by total assets), measured as the difference between $R O A$ and $A C C$, where $R O A$ is the profit after tax charges scaled by total assets. Accruals are subtracted from $R O A$ to undo the accrual

\footnotetext{
${ }^{11}$ To the extent that an increased presence of foreign banks in these districts is associated with an increase in timely loss recognition for firms in these districts (see Section 4.2.6), the inclusion of these districts as a control would cause us to understate the true causal effect of foreign bank entry.

${ }^{12}$ Comparing the summary statistics in Appendix Table 1 with those in Table 2 suggests that firms located in the areas with prior foreign bank entry are much larger in size, on average, than firms in our sample. They are also more profitable, as measured by their return on assets, and have higher operating cash flows. ${ }_{13}^{13}$ Our findings are also robust to restricting the sample to India's post-liberalization period of 1992-2002.

${ }^{14} \mathrm{We}$ use this methodology to calculate accruals as detailed cash flow data are largely unavailable in India.
} 
accounting methods used to calculate firms' cash flows and to better reflect the true level of current operating cash flows generated by the firm. $D C F O$ is an indicator variable equal to one if $C F O$ is negative, and zero otherwise.

Firms that engage in a timely recognition of economic gains and losses will exhibit a positive correlation between accruals, $A C C$, and contemporaneous cash flows, $C F O$. The positive correlation comes from the fact that cash flows generated from individual durable assets (such as plant and equipment) tend to be correlated over time (Ball and Shivakumar, 2005). For example, a piece of equipment that generates less cash today due to changes in product market conditions is also likely to experience a downward revision in its expected future cash flows. If these revisions of future cash flow expectations are incorporated into current-period accruals by a firm in a timely fashion, a positive correlation between accruals, $A C C$, and contemporaneous cash flows, $C F O$, will occur. In this example, a decline in expected future cash flows may be accounted for in accruals through a markdown in the value of assets or inventory.

The more timely firms are in their recognition of expected losses, the stronger the positive correlation between accruals, $A C C$, and operating cash flows, $C F O$, will be when cash flows are negative. Thus, the level of timely loss recognition is increasing in the coefficient, $\beta_{3}$. This will be our primary coefficient of interest throughout the paper. A timely recognition of gains would instead be captured by a positive correlation between cash flows and accruals when current cash flows are positive. However, because standard accounting practices generally do not allow firms to account for expected future gains in cash flows until those gains are actually realized, there is little positive correlation between positive cash flows and accruals on average. Instead, the use of accruals to mitigate cash flow noise generally causes a negative relation between cash flows and 
accruals (i.e. $\left.\beta_{2}<0\right)$ (Dechow, 1994; Dechow, Kothari, and Watts, 1998). ${ }^{15}$ This

asymmetry in the correlation between accruals and cash flows is why timely loss

recognition is often referred to as 'asymmetric timeliness'.

\subsection{Research design}

To test whether foreign bank entry is correlated with timely loss recognition, we expand model (1) by introducing a dummy variable, Bank, to capture foreign bank entry, and interact it with other explanatory variables in model (1). In particular, the model we estimate is specified as follows:

$$
\begin{aligned}
& A C C_{i d t}=\beta_{1} \mathrm{DCFO}_{i d t}+\beta_{2} \mathrm{CFO}_{i d t}+\beta_{3} \mathrm{DCFO}_{i d t} \times C F O_{i d t} \\
& +\beta_{4} \mathrm{Bank}_{d t}+\beta_{5} \mathrm{Bank}_{d t} \times D C F O_{i d t}+\beta_{6} \mathrm{Bank}_{d t} \times C F O_{i d t} \\
& +\beta_{7} \mathrm{Bank}_{d t} \times D C F O_{i d t} \times C F O_{i d t}+\alpha_{i}+\delta_{t}+\Gamma X_{i d t} \\
& +\delta_{t} \times D C F O_{i d t}+\delta_{t} \times C F O_{i d t}+\delta_{t} \times D C F O_{i d t} \times C F O_{i d t} \\
& +E_{d} \times D C F O_{i d t}+E_{d} \times C F O_{i d t}+E_{d} \times D C F O_{i d t} \times C F O_{i d t}+\varepsilon_{i t}
\end{aligned}
$$

where $B_{a n k}$ is equal to one if a foreign bank is present in district $d$ in year $t$, and zero otherwise. The regression includes firm fixed effects, $\alpha_{i}$, to control for time-invariant differences across firms, and year fixed effects, $\delta_{t}$, and year fixed effects interacted with $D C F O, C F O$, and $D C F O \times C F O$ to control non-secular time trends in average timely loss recognition across India. The regression also includes $D C F O, C F O$, and $D C F O \times C F O$ interactions with $E_{d}$, an indicator that equals one for the districts that eventually receive a foreign bank. These interactions control for average differences in timely loss recognition across the two types of districts. Time-varying controls, $X_{i d t}$, for size $(S I Z E)$, leverage $(L E V)$, and sales growth $(S G)$ along with their interaction with $C F O, D C F O$, and

\footnotetext{
${ }^{15}$ Firms use accrual accounting to mitigate noise in operating cash flows and to produce a better matching of expenses against revenues. For example, accrual accounting attempts to eliminate the transitory variations in cash flows by matching the cost of inventory sold, rather than current-period payments for inventory purchased, against sales revenue. This noise-reduction role of accruals will tend to create a negative correlation between accruals and cash flows from operations.
} 
$C F O^{*} D C F O$ are also included, where SIZE is natural log of total assets, $L E V$ is bank borrowings scaled by total assets, and $S G$ is sales growth, which is equal to ((sales $t_{t}-$ sales $\left.t_{t-1}\right) /$ sales $\left.t_{t-1}\right) .{ }^{16}$ Since foreign entry occurs at the district level, standard errors are clustered at the district-level.

By interacting Bank $k_{d t}$ with the main specification of Ball and Shivakumar (2005) and including the year and $E_{d}$ interactions, this new specification will make use of variation both in the location and in the timing of foreign bank entry to identify the impact of foreign bank entry on timely loss recognition. The main coefficient of interest, $\beta_{7}$, will test the changes in timely loss recognition for firms located in a district with a new foreign bank after its entry relative to changes for firms located elsewhere in India. A positive $\beta_{7}$ would support Hypothesis 1 (H1) and indicate that timely loss recognition increased for firms located near a new foreign bank after entry relative to other firms located elsewhere in India. $\beta_{6}$ captures any average change in the correlation between accruals and positive cash flows after foreign bank entry. Leuz, Nanda, and Wysocki (2003) argue that a larger negative relation between accruals and cash flows can indicate the smoothing of reported earnings that does not reflect underlying economic performance. If firms smooth earnings less after foreign bank entry, which would reflect another type of accounting improvement, we might also expect the coefficient, $\beta_{6}$, to be positive. This type of improvement would also cause a positive $\beta_{7}$, which again would be beneficial to lenders who are likely concerned about the use of smoothing in negative cash flow years to disguise bad performance.

The use of variation in both the location and timing of foreign bank entry reduces

\footnotetext{
${ }^{16}$ Market-to-book ratio is frequently used as a factor related with timely loss recognition. Due to the presence of unlisted public limited firms in our sample, we are unable to obtain market-to-book ratio for all firms. Instead, we use sales growth as an alternative proxy for growth opportunities.
} 
potential confounding effects that might arise from country-wide changes in accounting standards or fixed differences in reporting policies across firms. Changes in average timely loss recognition over time, which might arise from other country-level reforms or changes in financial competitiveness, would be absorbed by the year dummies and their interactions with $D C F O, C F O$, and $D C F O \times C F O$.

This difference-in-difference estimation relies on two identification assumptions. First, it implicitly assumes that the effect of foreign bank entry is localized and realized predominately by firms headquartered in the district with a foreign bank. In general, we expect this to hold as empirical work in other countries has demonstrated the average distance between firms and their bank is usually quite small. ${ }^{17}$ However, even if this assumption is not fully true, this would only bias the results against finding an effect of foreign bank entry on timely loss recognition because some firms affected by foreign bank entry would be wrongly classified as control firms in the estimation. ${ }^{18}$

The second identification assumption is that foreign banks did not select into districts that were already trending differently or going to trend differently in the future, with respect to firms' recognition of economic losses, for reasons unrelated to the actual entry. Consistent with this assumption, it is shown later that there is no evidence of differences in timely loss recognition across Indian districts prior to foreign bank entry.

\footnotetext{
${ }^{17}$ Analyzing small firms in the U.S., Petersen and Rajan (2002) finds that the average distance between a firm and its main bank was 67.8 miles in 1993, and the median distance was five miles. The Indian districts included in this sample had an average size of 2,457 square miles. While the U.S. firms sampled were on average six times smaller than the firms found in the Prowess data, it is likely the Indian firms also borrow locally as the positive relation between distance and borrowing costs is likely greater in a developing country such as India. Recent work on lending relationships and loan prices in Belgium and the U.S. also suggest that greater lending distances are associated with increased transportation and informational costs (Degryse and Ongena, 2005; Agarwal and Hauswald, 2007).

${ }^{18}$ As a robustness check, we also examine the relation between foreign bank entry and timely loss recognition for firms located in districts that share a border with a district that experiences foreign bank entry. Results suggest that timely loss recognition does not change for these firms after foreign bank entry, which lends empirical support to our identification assumption.
} 
There is also little reason to expect that foreign banks' location choices would be directly related to expectations of future changes in the conservatism of firms' financial statements. We come back to elaborate on this issue later in Section 5.1.

Another related concern, however, may be that foreign banks selected into districts with differential trends in growth opportunities and/or cash flow shocks and their persistence, which may itself be directly related to timely loss recognition. ${ }^{19}$ To account for this possibility, we also include controls for growth opportunities and other timevarying variables such as $S I Z E, L E V$, and $S G$ and each of the three controls is also interacted with $D C F O, C F O$, and $D C F O * C F O$ throughout the empirical analyses. By including these controls, our estimates will only pick up the affect of foreign bank entry on the timeliness of loss recognition that is not going through a differential change in one of these fundamentals. ${ }^{20}$ Our findings are also robust to including district-level controls for growth. These robustness tests are discussed in Section 5.1.

\section{Empirical results}

\subsection{Descriptive statistics}

Table 2 reports descriptive statistics for our sample of firms. The average total assets of firms in our sample is 2.5 billion Rupee (approximately $\$ 60$ million) and the median is 320 million $\mathrm{Rp}$ (approximately $\$ 7.4$ million). ROA (net income/assets) has a mean of -0.4 percent and a median of 1.2 percent, suggesting that on average, Indian firms incur losses. Accruals has a mean of -0.005 , indicating that accruals decrease income on average in India, and cash flows has a mean of 0 .

\footnotetext{
${ }^{19}$ Growth opportunities, leverage and size have each been linked to timely loss recognition (LaFond and Watts, 2007; Roychowdhury and Watts, 2007).

${ }^{20}$ Moreover, if foreign bank entry is causing a reduction in leverage or sales growth for some firms, as shown in Gormley (2010), then these time-varying controls will also capture any incremental effect that these changes in fundamentals might have on the timeliness of loss recognition.
} 
Profitability and cash flows of firms in districts where foreign bank entry occurs are similar to the profitability and cash flows of firms in districts with no foreign bank entry. Panel B presents separately the summary statistics for firms located in the districts with foreign bank entry $(\mathrm{N}=6,259)$, and Panel C presents summary statistics for firms located in districts with no foreign bank entry $(\mathrm{N}=14,175)$. On average, firms located in districts with foreign bank entry are slightly more profitable, and have higher accruals and lower cash flows compared to firms located in districts where foreign bank entry does not occur, but the differences are small and not statistically different.

[Insert Table 2 here]

\subsection{Regression results}

\subsubsection{Timely loss recognition prior to foreign bank entry}

Before we test our hypotheses, we first investigate whether timely loss recognition is present in India prior to foreign banks' entry beginning in 1994 and whether it varies across districts in a way that may raise concerns about our identification strategy. We do this by separately estimating equation (1), using only financial data from 1988-1993, for both districts that eventually receive a foreign bank and those that do not. We also include the time-varying controls for size, leverage, and growth along with their interactions as described earlier. The results are reported in Table 3.

Prior to foreign bank entry, there does not appear to be any evidence of timely loss recognition among Indian firms, and there is no evidence to indicate that the timely loss recognition was significantly different in districts that later experience foreign bank entry relative to districts that do not experience entry. The coefficient, $\beta_{3}$, is negative and statistically insignificant for firms located in districts that eventually experience foreign 
bank entry [Table 3, Column (i)] and among firms located in districts that do not experience entry [Table 3, Column (ii)]. This finding lends support to our identification assumption that timely loss recognition in the districts with foreign bank entry is not significantly different from that in other districts prior to foreign bank entry. This finding is also consistent with the evidence from Bushman and Piotroski (2006) that less developed debt and equity markets, together with weak legal protections, contribute to a lower level of timely loss recognition. Lastly, the coefficient, $\beta_{2}$, is negative and statistically significant for both groups of firms, confirming the use of accruals to mitigate cash flow noise.

[Insert Table 3 here]

\subsubsection{Timely loss recognition following foreign bank entry}

Based on the first hypothesis, we predict that firms located in the foreign bank entry districts will increase timely loss recognition after foreign bank entry. The OLS estimates of equation (2) are reported in Table 4. Consistent with our hypothesis, the coefficient on the variable of interest, $\beta_{7}$, is positive and statistically significant at the five percent significance level. This result also indicates that firms reduce the smoothing of earnings in negative cash flow years after foreign bank entry. The increase in timely loss recognition after foreign bank entry is not only statistically significant, but is also economically significant. The incidence of foreign bank entry increases timely loss recognition by about seventy-five percent from 0.129 to 0.226 . The negative and insignificant coefficient, $\beta_{6}$, suggests that the smoothing of earnings in positive cash flow years does not change after foreign bank entry.

[Insert Table 4 here] 
This increase in timely loss recognition following foreign bank entry is robust to controlling for other important factors that are known to affect timely loss recognition (e.g., Beatty, Weber, and Yu, 2008; Zhang, 2008). The estimates in Table 4 include controls for size, leverage, and growth, and their interactions with $D C F O, C F O$, and $D C F O^{*} C F O$. The increase is also not driven by country-level changes in accounting practices. ${ }^{21}$ The year dummies interacted with $D C F O, C F O$, and $D C F O \times C F O$ would capture any country-wide change in reporting policies during the sample period.

One concern might be that other country-level accounting or financial reforms during the sample period may be differentially affecting the firms in the districts experiencing foreign bank entry. In this case, our estimation may be wrongly attributing the improvements in conservatism to the impact of foreign bank entry. To test for a possible pre-existing, differential trend in timely loss recognition, we estimate a modified version of equation (2), where we allow the effect of foreign bank entry to vary by year in a five-year window surrounding foreign bank entry into each district. The yearly point estimates of $B A N K \times D C F O \times C F O$ are reported in Figure 2.

[Insert Figure 2 here]

The timing of the increase in timely loss recognition coincides with foreign bank entry. As seen in Figure 2, there is no indication of a differential trend in timely loss recognition prior to foreign bank entry; firms located in districts experiencing foreign bank entry do not appear to be trending differently prior to foreign bank entry. ${ }^{22}$ But after entry, firms located in a district with foreign entry tend to increase their timely loss

\footnotetext{
${ }^{21}$ Accounting practices may be related to accounting standards (E.g. Joos and Lang, 1994; Barth, Clinch, and Shibano, 1999; Ashbaugh and Pincus, 2001; Leuz, 2003), tax systems (Guenther and Young, 2000), institutional factors (Ali and Hwang, 2000; Ball, Kothari, and Robin, 2000; Leuz, Nanda, and Wysocki, 2003; Leuz, 2006), and political connections (Chaney, Faccio, and Parsley, 2009).

${ }^{22}$ The plotted coefficients measure the change in $B A N K \times D C F O \times C F O$ (from its level in the initial sample year) for affected firms relative to other firms. The confidence intervals shown have much less power than estimates from equation (2) because they compare each year separately against the reference period.
} 
recognition relative to firms located in other districts. The precise timing of the shift in accounting conservatism suggests that it is in fact caused by foreign bank entry, rather than by any omitted firm characteristic or other country-level reforms. In order for other country-level reforms to drive this shift, it must be that they differentially affect firms located in districts experiencing foreign bank entry, and do so at various points in time coinciding with foreign bank entry into each different district between 1994 and 2002.

The increase in timely loss recognition is also robust to restricting the sample to only firms located in eight districts experiencing foreign bank entry. In doing this, we further exclude the possibility that differential trends between firms located in the districts with foreign bank entry and those that never experience such entry are driving our findings. These robustness tests are discussed further in Section 5.

\subsubsection{Cross-sectional changes in timely loss recognition}

Our second hypothesis predicts that certain firms - those that are more dependent on external financing - are more likely to increase timely loss recognition when changes in the lending environment increase the demand for conservative financial statements. We analyze this possibility by re-estimating equation (2) based on subsamples of firms broken down by size, legal ownership, group-affiliation, and need for external financing. These estimates are reported in Tables 5-8.

Splitting the full sample into two groups based on the median of assets, we find that the increase in the timely loss recognition is greater, on average, among smaller firms. This is seen in Table 5, where the coefficient on the variable of interest, $\beta_{7}$, is positive and statistically significant at the ten percent level for firms with assets below the median sample value [Table 5, Column (ii)] but negative and non-significant for firms with assets above the median value [Table 5, Column (i)]. This result suggests that smaller firms 
disproportionally increased timely loss recognition after foreign bank entry, which is consistent with Hypothesis $2 .{ }^{23}$ The difference in the estimate of $\beta_{7}$ between the small and the large firms is statistically significant at the five percent level. In addition, the coefficient, $\beta_{2}$, is greater in absolute value for large firms than for small firms, which is consistent with Ball and Shivakumar (2005) who argue that accruals mitigate more cash flow noise in larger firms. The coefficient, $\beta_{6}$, is negative but statistically not significant for both large and small firms, suggesting that the mitigating role of accruals in cash flow noise and the smoothing of reported earnings for positive cash flow years does not change across firm size after foreign bank entry.

\section{[Insert Table 5 here]}

The increase in timely loss recognition also appears larger, on average, among private firms. This is seen in Table 6, where we split between public and private firms. While we find a statistically significant increase in timely loss recognition for public firms [Column (i)], the average increase among private firms [Column (ii)] is nearly twice as large as that of public firms, and the difference between public and private firms is statistically significant at the ten percent level. This evidence is consistent with the argument that private firms may be more dependent on bank financing than public firms.

\section{[Insert Table 6 here]}

We also find an increase in timely loss recognition among non-group firms, which may be more dependent on external financing. This is shown in Table 7 where the results are reported separately based on firms' group-affiliation. The increase in timely loss recognition is statistically significant among non-group firms [Table 7, Column (ii)], whereas the increase for group firms is smaller and not statistically significant [Table 7 ,

\footnotetext{
${ }^{23}$ It is also possible this finding reflects larger firms' ability to borrow from lenders at a greater distance and that these firms are less subject to changes in the local credit market.
} 
Column (i)]. However, there is no conclusive evidence that group and non-group firms respond differentially to foreign bank entry: the difference in timely loss recognition between group and non-group firms is not statistically significant.

[Insert Table 7 here]

We next test whether the change in timely loss recognition varies by a firm's external financing dependence using industry-level variation following the methodology of Rajan and Zingales (1998). Assuming that industry-level external financing needs are persistent across countries, we measure external financing dependence at the industry level for Indian firms using data from U.S. firms. ${ }^{24} \mathrm{We}$ then split the sample into firms with above median external financing dependence, and those with below median dependence. The estimates are reported in Table 8 .

We find evidence that private firms with more external dependence increase timely loss recognition significantly after foreign bank entry. More specifically, in columns (i) and (ii) where we report the estimates using the full sample, $\beta_{7}$ is not statistically significant for either high or low dependence firms. When we restrict the sample to private firms, as done in columns (iii) and (iv), we find that high external dependence firms increase timely loss recognition significantly after foreign bank entry while the increase for low external dependence firms is less than half as large and not statistically significant at conventional levels. The difference between high and lowdependence, private firms, however, is not statistically significant (the p-value of the

\footnotetext{
${ }^{24}$ Since Rajan and Zingales's external financing measure is only available for manufacturing industries, we lose about one third of our observations in these regressions. Rajan and Zingales (1998) measure industry external financing needs using international standard industries classification and data for U.S. public firms from Compustat. Specifically, they calculate the portion of capital expenditure (Item \#128) that is not financed by the cash flows generated from business operations ((Item \#110) + decrease in inventory (Item $\# 3)+$ decrease in accounts receivable (Item \#2) + increase in accounts payable (Item \#70)) and scaled by capital expenditure. See Rajan and Zingales (1998) for more details on how this measure is constructed.
} 
difference is 0.176 ).

[Insert Table 8 here]

Taken together, the results in Tables 5-8 suggest that certain firms - those that are more dependent on external debt funding - are more likely to increase their timely loss recognition when foreign bank entry occurs. The evidence also suggests that the increase in timely loss recognition is not just concentrated among foreign banks' borrowers, which tend to be larger, more established firms (Berger, Klapper, and Udell, 2001; Haber and Musacchio, 2004; Mian, 2006; Gormley, 2010). This is consistent with timely loss recognition becoming more important in domestic banks' lending decisions after foreign bank entry, which might occur if domestic banks adopt the 'best practices' of foreign banks or if they increase their intensity of screening and monitoring loans.

Overall, this evidence reinforces the importance of timely loss recognition and its potential impact on debt contracts (Ahmed, Billings, Morton, and Harris, 2002; Beatty, Weber, and Yu, 2008; Guay, 2008; Wittenberg-Moerman, 2008; Zhang, 2008). The evidence also supports the argument of Ball (2001) and Kothari (2001) that institutional mechanisms are important in shaping accounting choices. Previous research has explored the relation between accounting practices and legal institutions (Ball, Kothari, and Robin, 2000), equity market development and investor rights (Leuz, Nanda, and Wysocki, 2003), tax systems (Ali and Hwang, 2000; Guenther and Young, 2000) and political connections (Chaney, Faccio, and Parsley, 2009). These findings suggest that banking sector characteristics may also be important in shaping accounting practices over time.

\subsubsection{Timely loss recognition and access to credit}

In this section, we test our third hypothesis of whether the increase in timely loss recognition is correlated with firms' access to credit markets. An underlying assumption 
of the previous analyses is that lenders value conservative financial reports when making lending decisions. Absent this, it would be difficult to understand why firms' timely loss recognition increases after foreign bank entry.

To test this underlying assumption, we analyze whether the increase in timely loss recognition is accompanied by an increase in credit access among firms in districts that experience foreign bank entry. To do this, we first re-estimate equation (2) using only the firm-year observations of firms located in the eight districts that experience foreign bank entry over the sample period. The estimates from using this more restrictive sample, which are reported in column (i) of Table 9, confirm our earlier findings. The increase of timely loss recognition after foreign entry is still positive and statistically significant at the one percent level.

[Insert Table 9 here]

To test whether the increase in timely loss recognition is associated with better access to credit for firms, we then divide the sample into firms that experience an increase in debt levels after foreign entry and those that do not. This is done based on whether a firm's overall amount of bank borrowings increases or declines following foreign bank entry. If a firm experiences an average decline in total bank borrowings in the three years after foreign bank entry, we include it in the 'debt-reduction' group, otherwise we include it in the 'no debt-reduction' group. In total there are 2,961 firm-year observations that do not experience credit declines, and 3,298 firm-year observations that do. If the increase in timely loss recognition helps alleviate credit constraints, then we expect that the increase in timely loss recognition will be more pronounced for firms in the 'no debt-reduction' group than firms in the 'debt-reduction' group.

In fact, this is exactly what the evidence appears to indicate. There is only an 
increase in timely loss recognition among firms not experiencing a drop in overall credit. This is seen in Table 9, columns (ii) and (iii), where the coefficient, $\beta_{7}$, is 0.189 for the non-debt reduction subsample and statistically significant at the one percent level compared to a non-significant coefficient of only 0.002 for the debt reduction subsample. The difference in $\beta_{7}$ between the two groups of firms is statistically significant at the five percent level. The result suggests more timely loss recognition was associated with better access to credit markets following foreign bank entry and that lenders value timely loss recognition when making lending decisions. ${ }^{25}$

\subsubsection{Timely loss recognition and accounting practices}

We next investigate whether foreign bank entry is related to changes in specific accounting practices that would potentially contribute to the increase in timely loss recognition. Similar to before, we restrict our sample to firms in districts that experience foreign bank entry, but we now regress a number of accounting choice variables that might reflect greater conservatism onto the indictor for a foreign bank's presence, $B A N K$, firm fixed effects, and year fixed effects. The coefficient on $B A N K$ will estimate the extent to which firms' accounting choices change after foreign bank entry relative to changes among firms located in districts yet to receive a foreign bank. Our estimates also include time-varying controls for firms' size and sales growth. The estimates are reported in Table 10.

[Insert Table 10 here]

\footnotetext{
${ }^{25}$ Combined with the findings of Gormley (2010), where the small firms, on average, experience a drop in loans, and our earlier finding that small firms, on average, increase their timely loss recognition, this finding suggests a heterogeneous response among small firms. Some small firms increase timely loss recognition and maintain their access to credit, whereas others do not and experience a decline in credit. The finding in Table 9 also suggests that the average decline in credit for small firms would have been even worse absent the observed increase in timely loss recognition.
} 
We find evidence that foreign bank entry is associated with changes in accounting practices that might contribute to the overall increased conservatism in their financial statements. As seen in Table 10, column (i), foreign bank entry is associated with an increase in write-offs of fixed assets normalized by average gross fixed assets. This is consistent with firms being more conservative by timely marking down the value of assets upon negative shocks. In columns (ii) and (iii), we find increases in bad debt expenses normalized by total account receivables and extraordinary expenses normalized by total sales. Both increases can contribute to an increase in conservatism. We also find an increase in the provision of contingencies scaled by total assets, but the increase is not statistically significant.

\subsubsection{Timely loss recognition and the extent of foreign bank entry}

In this section, we test whether the change in timely loss recognition increases with the extent of foreign bank entry. Theoretically, it is not clear whether such a positive relation would exist. If increased conservatism is partially driven by foreign lenders demanding greater timely loss recognition among their clients, then greater foreign entry might increase the number of firms with foreign bank relationships and increase the amount of timely loss recognition. On the other hand, it is possible that the increase in conservatism is driven by the initial entry of foreign lenders rather than the extent of their entry. This might occur if domestic lenders attempt to adopt the "best practices' of the foreign bank or if the mere arrival of a new lender and the threat of greater competition shifts the equilibrium behavior of incumbent lenders (E.g., see Petersen and Rajan, 1995; Dell'Arricia and Marquez, 2004; Segupta, 2007; Gormley 2010). In this case, the observed increase in timely loss recognition may not increase 
with the extent of foreign bank entry.

To test whether the extent of foreign bank entry is related to timely loss recognition, we divide our sample based on the extent of foreign bank entry in the eight districts that experienced entry. In particular, we calculate the share of branches held by foreign banks in these eight districts at the end of the sample period, and estimate our main specification separately for the four districts with the highest share of foreign bank branches and the four districts with the lowest share. The results are reported in Table 11.

[Insert Table 11 here]

We find inconclusive evidence on whether the increase in timely loss recognition is larger in districts with greater foreign bank entry. For firms located in districts with high market share of foreign banks, the point estimate on $B A N K^{*} D C F O * C F O$ is 0.116 and significant at five percent confidence level, while for the firms in districts with less entry, the point estimate is smaller and not statistically significant. The difference between the two subsamples, however, is not significantly different (the p-value of the difference is 0.28 ).

\section{Robustness tests}

\subsection{Selection bias}

While there is no evidence in Table 3 and Figure 2 to indicate that the levels and trends of timely loss recognition looked different across districts in India prior to foreign bank entry, one concern with the above identification strategy is that foreign banks selectively entered districts where levels of timely loss recognition were going to trend upward in the future for reasons unrelated to foreign bank entry. For example, a selection bias might occur if foreign banks choose to locate in regions of India in anticipation of 
future improvements in the conservatism of firms' financial statements. If this occurred, the observed correlation between timely loss recognition and foreign bank entry could be driven by foreign banks' location choice rather than an increase in the benefit of providing more conservative financial statements to lenders.

The observed increases in timely loss recognition, however, do not appear to be driven by foreign banks' expectations of future accounting changes or firm-level growth opportunities. First, accounting standards are set at the national level in India, which makes a foreign bank's choice of location based on expectations about regional changes in accounting policies unlikely. ${ }^{26}$ It is also unclear why national changes in accounting regulation would affect firms heterogeneously and do so at different points in time that happens to coincide with foreign bank entry into each of the districts. Second, all our estimates include controls for firm-level sales growth, which may be related to both accounting changes (LaFond and Watts, 2007; Roychowdhury and Watts, 2007) and foreign bank entry. Our results are also robust to including district-level controls for growth, consisting of either the natural logarithm of the number of firms or the natural logarithm of the number of banks in a district.

Our earlier analysis in Table 9 also suggests that selection bias is not driving our results. In those estimates, the sample is restricted to only firms located in the eight districts that experience foreign bank entry during the sample time period. In doing this, we further exclude the possibility that differential trends between firms located in the districts with foreign bank entry and those that never experience such entry are driving our earlier findings. As noted earlier, foreign bank entry is still positively associated with

\footnotetext{
${ }^{26}$ In addition to the financial reforms discussed earlier, there were some country-level changes in accounting standards in India during the sample time period. Details of these miscellaneous changes are provided on the website of The Institute of Chartered Accountants of India, www.icai.org.
} 
an increase in timely loss recognition in this restricted sample [Table 9, column (i)]. ${ }^{27}$

\subsection{Other possible channels}

Our evidence is consistent with the increase in timely loss recognition after foreign bank entry being driven by a change in the demand for more conservative financial statements. However, it is also possible that foreign bank entry affects firms' fundamentals negatively via reduced credit access, and in return, the change in fundamentals affects the accrual-cash flow relation. While our existing time-varying controls for size, leverage, sales growth, and their interactions with $D C F O, C F O$, and $D C F O{ }^{*} C F O$ would likely capture any effect of foreign bank entry on timely loss recognition through such shifts in firms' fundamentals, we conduct four additional robustness tests to address this possible concern.

First, we test whether there is any change in profitability, accruals, or operating cash flows following foreign bank entry that is not captured by our existing controls. To do this, we regress these fundamentals onto our main variable of interest, $B A N K$, in a panel regression that includes both our time-varying controls for size, leverage, and sales growth and firm and year fixed effects. In untabulated results, we find no incremental association between foreign bank entry and profitability, accruals, or operating cash flows. This suggests that our controls for size, leverage, and sales growth, are adequately capturing any shifts in firm fundamentals caused by foreign entry. ${ }^{28}$

\footnotetext{
${ }^{27}$ As another robustness test, we also re-estimated our main specification in Table 4 using an instrumental variable (IV) regression that uses the same instrument for foreign bank entry as Gormley (2010), the geographical distribution of foreign firms in India before the WTO agreement. In untabulated results, we found the IV point estimate for $B A N K^{*} D C F O^{*} C F O$ to be positive and of similar magnitude to the OLS estimate in Table 4. While this further suggests that our findings are not driven by a selection bias related to foreign banks' location choices, the IV point estimate is very noisy with a p-value of 0.849 .

${ }^{28}$ In addition, we also test whether there is an incremental change in these fundamentals among firms where we find the change in timely loss recognition to be more pronounced: small firms, non-group firms, private firms, and firms with greater external financing needs. We do not find any evidence of this.
} 
Second, we test the robustness of our findings to adding even more controls for fundamentals that might be related to both cash flow shocks and foreign bank entry. These factors include total loans from financial institutions, whether a firm has a bank loan, $R O A$, cash holdings scaled by total assets, and capital expenditures scaled by total assets. We also include these controls interacted with $D C F O, C F O$, and $D C F O \times C F O$. Our main finding remains unaltered after including these additional controls.

Third, we examine whether the increase in timely loss recognition after foreign bank entry is more pronounced only among firms where credit access is adversely affected by foreign bank entry, as documented in Gormley (2010). Gormley (2010) shows that credit drops are more significant for smaller firms, group firms, firms with fewer tangible assets, and firms more dependent on external financing. We find, however, that the increase in the timeliness does not perfectly overlap with these earlier findings. ${ }^{29}$ The lack of a complete overlap suggests that the changes in timely loss recognition are not merely driven by the drop in credit access documented in Gormley (2010).

A possible decline in credit access and its negative cash flow impact also cannot explain the observed correlation between changes in debt and timely loss recognition. Table 9 shows that firms that increase the timeliness of loss recognition the most are least likely, on average, to experience a debt reduction after foreign bank entry occurs. This suggests that negative shocks to credit access cannot fully explain the increase in timely loss recognition after foreign bank entry as this would tend to imply that the increase would predominately occur among firms experiencing debt reductions.

Fourth, we test whether the increase in timely loss recognition is only

\footnotetext{
${ }^{29}$ While we do find an increase in the timeliness for smaller firms and firms with more external financing needs, we do not find an increase among group firms (see Table 7). Furthermore, Gormley (2010) finds that credit drop is greater for firms with few tangible assets, but in untabulated results, we find no difference in the change in timeliness based on the tangibility of firms' assets.
} 
concentrated among the least profitable firms, where declines in credit access are more likely (Gormley 2010). Dividing our sample between the top $10 \%$ of firms (in terms of profitability) and all other firms, as done in Gormley (2010), we find a similar average increase in timely loss recognition for both sets of firms. ${ }^{30}$ This again suggests that our findings are not driven by a deterioration in fundamentals.

\subsection{Alternative measure of accounting quality}

Throughout the paper we use timely loss recognition to measure the conservatism of borrowers' financial statements since this form of conservative financial reporting is argued to improve debt contracting efficiency. In this section, we apply an alternative measure of accounting quality that may be of interest to lenders, the positive correlation between current net income, $\mathrm{NI}_{t}$, and future operating cash flows, $\mathrm{CFO}_{t+1}{ }^{31}$

The results based on using this alternative measure of accounting quality are less conclusive. These findings are presented in Table 12. In column (i), the positive and significant coefficient on $B A N K^{*} N I$ indicates that the ability of net income to positively predict future cash flows increases significantly after foreign bank entry, which is consistent with improved informativeness. ${ }^{32}$ In column (ii), net income, $N I$, is broken

\footnotetext{
${ }^{30}$ The coefficient on $B A N K^{*} D C F O * C F O$ is 0.089 in both subsamples. While the increase in timeliness is not statistically significant in the much smaller sample of very profitable firms, we cannot reject the hypothesis that the observed increase in timeliness is the same in both subsamples.

${ }^{31}$ Minnis (2011) argues that an increasing positive correlation between $\mathrm{NI}_{t}$ and $\mathrm{CFO}_{t^{+}+}$reflects an improved ability of the financial statement data to predict future cash flows, which is particularly relevant to lenders who use current financial statements to assess borrowers' ability of paying back debt in the future. In support of this argument, Minnis (2011) finds a stronger positive correlation for firms with audited financial reports, which tend to borrow at a lower cost compared to firms with unaudited financial reports.

${ }^{32}$ As emphasized by Minnis (2011), however, this improved predictability need not imply increased conservatism. In fact, more conservative financial reporting will reduce predictability unless it is associated with less reporting asymmetry. Such a decline in reporting asymmetry appears to be occurring in our setting given we find both an increase in conservatism and predictability. Furthermore, as seen in Table 3, Column (i), the coefficient on $D C F O \times C F O$ is negative suggesting that Indian firms do not report conservatively prior to foreign bank entry. In this scenario, an increase in conservatism can both reduce reporting asymmetry and improve predictability.
} 
down into cash flows, $C F O$, and accruals, $A C C$. Minnis (2011) argues that the coefficient on cash flows gauges the persistence of underlying business fundamentals while the coefficient on accruals captures borrowers' discretion in improving quality. As shown in column (ii), both of their interactions with $B A N K$ are positive and statistically significant at the one percent confidence level. While the positive interaction between $B A N K$ and $A C C$ is consistent with an improvement in managerial discretion in financial reporting after foreign bank entry, we are unable to exclude the possibility that a shift in business fundamentals might be driving this positive interaction, as suggested by the positive interaction between $B A N K$ and $C F O$.

\section{[Insert Table 12 here]}

\subsection{Further discussion}

It is worth emphasizing that our findings may not be applicable to foreign bank entry into developed countries. As discussed earlier, the weak accounting standards and legal protections in India may contribute to the increase in timely loss recognition for firms in India. To the extent that this particular channel is driving our findings, we may not expect to find similar results when foreign bank entry occurs in more developed countries, like the U.S. However, if our findings are instead driven by other channels, such as the arrival of a relatively less informed lender that needs to rely more heavily on information contained within financial statements, our findings would still be applicable to other scenarios in developed countries, such as the entry of new banks into markets dominated by incumbent banks that may be more informed about local firms.

Our paper suggests that foreign banks and/or local lenders demand more timely loss recognition when foreign banks enter India and that borrowers correspondingly 
increase conservatism. A question that our analysis does not analyze is what mechanisms prevent borrowers from subsequently reducing their timely loss recognition after obtaining a loan. One possible mechanism is reputational considerations or repeated interactions with lenders. Borrowers may be concerned about their ability to obtain credit from the same lender in the future if they do not maintain conservative financial statements. Another possible mechanism is through high quality audits. Borrowers may switch to auditors with strong reputations, such as the Big Five international auditors, as a commitment device to maintain more conservative financial statements. Unfortunately, our available data do not allow us to test these hypotheses.

\section{Conclusion}

While ample theory and evidence suggest that firms should adjust their accounting policies in response to changes in the banking sector that affect the costs and benefits of being conservative, there is little direct evidence of this occurring. Empirical evidence is sparse in part because of the difficulty of isolating a change in the benefits of being conservative that is not also related to other factors that may affect reporting policies. Our paper overcomes this challenge by exploiting an exogenous increase in the benefit of being conservative caused by the entry of foreign banks into India during the 1990s. Using this framework, we assess whether firms adjust their timely recognition of losses in response to changes in the banking industry.

Overall, we find evidence that firms attempt to improve the conservatism of their financial statements following changes in the lending environment that increase the benefits of being more transparent to lenders. In particular, we find that the average level of timely loss recognition increases for firms located in the vicinity of new foreign banks 
following their entry into India. The increases in timely loss recognition are also concentrated among debt-dependent firms that may have a stronger incentive to alleviate financing constraints by reducing information asymmetries and agency costs of debt. Specifically, we find that smaller, non-group, and private firms appear to respond to changes in the lending environment the most. Private firms with greater dependence on external financing also appear to respond more than the average firm, and lenders seem to value these changes. Specifically, firms that improve the most were, on average, more likely to experience an increase in their debt level after foreign bank entry.

Our evidence suggests the financial market reforms, banking industry changes in particular, may be another channel through which countries may influence firms' financial reporting choices. Contrary to changes in regulations regarding disclosure and auditing rules, which directly affect firms' accounting policies, our evidence suggests that banking sector characteristics may indirectly affect financial reporting choices by improving firms' incentive to produce more conservative financial statements. 


\section{REFERENCES}

Ahmed, A.; B. BILlings; R. Morton; AND M. HARRIS. "The Role of Accounting Conservatism in Mitigating Bondholder-Shareholder Conflicts over Dividend Policy and in Reducing Debt Costs." The Accounting Review 77(4) (2002): 867-890.

AGARWAL, S., AND HaUSWALD, R. "Distance and information asymmetries in lending." Unpublished manuscript. Federal Reserve Bank of Chicago (2007).

ALI, A., AND L. HwANG. "Country-Specific Factors Related to Financial Reporting and the Value Relevance of Accounting Data." Journal of Accounting Research 38(1) (2000): 1-21.

ARMStrong, C., W. GUAY, J. WeBER. "The role of information and financial reporting in corporate governance and debt contracting." Journal of Accounting and Economics 50 (2010): 179-234.

ASHBAUGH, H., AND M. PINCUS. "Domestic accounting standards; international accounting standards, and the predictability of earnings." Journal of Accounting Research 39(3) (2001): 417-34.

BALL, R.; S. P. KOTHARI; AND A. ROBIN. "The effect of international institutional factors on properties of accounting earnings." Journal of Accounting and Economics 29(1) (2000): 1-51.

BALL, R. "Infrastructure Requirements for an Economically Efficient System of Public Financial Reporting and Disclosure."' Brookings-Wharton Papers on Financial Services 2(1) (2001): 127-169.

BALL, R., AND L. SHIVAKUMAR. "Earnings quality in UK private firms: comparative loss recognition timeliness." Journal of Accounting and Economics 39(1) (2005): 83-128.

BALL, R.; A. RoBIN; AND G. SADKA. "Is Financial Reporting Shaped by Equity Markets or by Debt Markets? An International Study of Timeliness and Conservatism." Review of Accounting Studies 13 (2008): 168-205.

BALL, R; A. ROBIN; AND WU, J. "Incentives versus standards: properties of accounting income in four East Asian countries and implications for acceptance of IAS." Journal of Accounting and Economics 36 (2003):235-270.

BARTH, M.E.; G. ClinCH; AND T. SHIBANO. "International accounting harmonization and global equity markets." Journal of Accounting and Economics (26) (1999): 201-35.

BASU, S. "The conservatism principle and the asymmetric timeliness of earnings." Journal of Accounting and Economics (24) (1997): 3-37.

BEATTY, A.; J. WeBER; AND J. YU. "Conservatism and Debt." Journal of Accounting and Economics 45(2-3) (2008): 154-174.

Berger, A.N.; KLAPPER, L.F.; PERIA, M.S.M.; AND ZAIDI, R. "Bank ownership type and banking relationships." Journal of Financial Intermediation 1 (2008), 37-62.

BERGER, A. N.; L. F. KLAPPER; AND G.F. UDELL. "The ability of banks to lend to informationally opaque small businesses." Journal of Banking \& Finance 25 (2001): 2127-2167. 
Bushman, R., AND J. PIOTROSKI. "Financial Reporting Incentives for Conservative Accounting: The Influence of Legal and Political Institutions." Journal of Accounting and Economics 42 (1-2) (2006), 107148.

ChANEY, P.; M. FACCIO; AND D. PARSLEY. "The quality of accounting information in politically connected firms." working paper, 2009.

Clarke, G. R. G.; R. CUlL; AND M.S. MARTINEZ PeRIA. "Foreign bank participation and access to credit across firms in developing countries." Journal of Comparative Economics 34(4) (2006): 774-795.

Claessens, S.; A. Demirguc-Kunt; AND H. Huizinga. "How does foreign bank entry affect the domestic banking market." Journal of Banking and Finance 25(5) (2001): 891-911.

DECHOW, P. "Accounting earnings and cash flows as measures of firm performance: The role of accounting accruals." Journal of Accounting and Economics 18(1) (1994): 3-42.

DECHOw, P. M.; S. P. KothaRI; AND R.L. WATTS. "The relation between earnings and cash flows." Journal of Accounting and Economics 25(2) (1998): 133-168.

DEGRYSE, H., AND ONGENA,S. "Distance, lending relationships, and competition." Journal of Finance 60 (2005): 231-266.

DELL'ARICCIA, AND G.R. MARQUEZ. "Information and bank credit allocation." Journal of Financial Economics 72 (2004): 185-214.

Detragiache, E.; Gupta, P.; And Tressel, T. "Foreign Banks in Poor Countries: Theory and Evidence." Journal of Finance, 63(5) (2008).

DiAmond, D. "Financial Intermediation and Delegated Monitoring." Review of Economic Studies 51(3) (1984): 393-414.

GiAnNETTI, M., AND S. ONGENA. "Financial Integration and Firm Performance: Evidence from Foreign Bank Entry in Emerging Markets." Review of Finance 13(2) (2009a): 181-223.

GIANNETTI, M., AND S. ONGENA. "Lending by Example": Direct and Indirect Effects of Foreign Banks in Emerging Markets." Working paper, Stockholm School of Economics and Tilburg University, 2009b.

GORMLEY, TODD A. "Costly Information, Foreign Entry, and Credit Access." working paper, 2007.

GORMLEY, TODD A. "The Impact of Foreign Bank Entry in Emerging Markets: Evidence from India." Journal of Financial Intermediation 19(1) (2010): 26-51.

GUAY, W. R. "Conservative financial reporting, debt covenants, and the agency costs of debt." Journal of Accounting and Economics 45(2-3) (2008): 175-180.

GUENTHER, D.A., AND D. YOUNG. "The association between financial accounting measures and real economic activity: a multinational study." Journal of Accounting and Economics 29(1) (2000): 53-72. 
HABER, S. H., AND A. MUSACCHIO. "Foreign Banks and the Mexican Economy." Division of Research, Harvard Business School, 2004.

JoOS, P., AND M. LANG. "The Effects of Accounting Diversity: Evidence from the European Union." Journal of Accounting Research 32 (1994): 141-168.

KOTHARI, S. P. "Capital markets research in accounting." Journal of Accounting and Economics 31(1-3) (2001): 105-231.

LAFOND, R., AND R. L. Watts. "The information role of conservative financial statements." The Accounting Review (2007).

LENSINK, R., AND N. HERMES. "The short-term effects of foreign bank entry on domestic bank behaviour: does economic development matter?" Journal of Banking and Finance 28 (2004), 553-568.

LeONE, A.; S., ROCK; AND M., WillenBORG. "Disclosure of Intended Use of Proceeds and Underpricing in Initial Public Offerings." Journal of Accounting Research 45 (1) (2007), 111-153.

LEUZ, C. "IAS versus U.S. GAAP: Information Asymmetry-Based Evidence from Germany's New Market." Journal of Accounting Research 41(3) (2003): 445-472.

LEUZ, C. "Cross listing, bonding and firms' reporting incentives: A discussion of Lang, Raedy and Wilson." Journal of Accounting and Economics 42(1-2) (2006): 285-299.

LEUZ, C.; NANDA, D.; AND P., WYSOCKI. "Earnings management and investor protection: an international comparison." Journal of Financial Economics 69 (2003), 505-527.

MiAn, A. "Distance Constraints: The Limits of Foreign Lending in Poor Economies." The Journal of Finance 61(3) (2006): 1465-1505.

MinNIS, MiCHAEL. "The Value of Financial Statement Verification in Debt Financing: Evidence from Private U.S. Firms." Journal of Accounting Research 49(2) (2011): 457-506.

NikolaeV, N. "Debt Covenants and Accounting Conservatism." Journal of Accounting Research 48 (1) (2010): 137-176.

Petersen, M. A., And RAJAn, R. G. "The Effect of Credit Market Competition on Lending Relationships." Quarterly Journal of Economics 110(2) (1995): 407-443.

Petersen, M.A., AND RAJAN, R.G. "Does distance still matter? The information revolution in small business lending." Journal of Finance 57 (2002), 2533-2570.

RAJAN, R.G., AND L. ZINGALES. "Financial Dependence and Growth." American Economic Review 88(3) (1998): 559-586.

RAMAKRISHNAN, R., AND A. V. THAKOR. "Information Reliability and a Theory of Financial Intermediation." Review of Economic Studies 51(3) (1984): 415-32.

RoBERTS, M., AND A. SUFI. "Control Rights and Capital Structure: An Empirical Investigation." Journal of Finance, 64(4) (2009), 1657-1695. 
ROYCHOWDHURY, S., AND R. L. WATTS. "Asymmetric timeliness of earnings, market-to-book and conservatism in financial reporting." Journal of Accounting and Economics 44(1-2) (2007): 2-31.

SENGUPTA, R. "Foreign entry and bank competition." Journal of Financial Economics 84(2) (2007): 502528.

STEIN, J. C. "Information Production and Capital Allocation: Decentralized versus Hierarchical Firms." Journal of Finance, 57(5) (2002): 1891-1921.

WATTS, R. L. "Conservatism in Accounting Part I: Explanations and Implications." Accounting Horizons 17(3) (2003a): 207-222.

WATts, R. L. "Conservatism in Accounting Part II: Evidence and Research Opportunities." Accounting Horizons 17(4) (2003b): 287-302.

Watts, R.L., AND J. L. Zimmerman. "Positive Accounting Research." Englewood Cliffs, NJ: Prentice Hall, 1986.

WillenborG, M. "Empirical Aanalysis of the Economic Demand for Auditing in the Initial Public Offering Market." Journal of Accounting Research 37 (1) (1999): 225-238.

WITTENBERG-MOERMAN, R. "The role of information asymmetry and financial reporting quality in debt contracting: Evidence from the secondary loan market." Journal of Accounting and Economics, 2008.

ZHANG, J. "The contracting benefits of accounting conservatism to lenders and borrowers." Journal of Accounting and Economics 45(1) (2008): 27-54. 


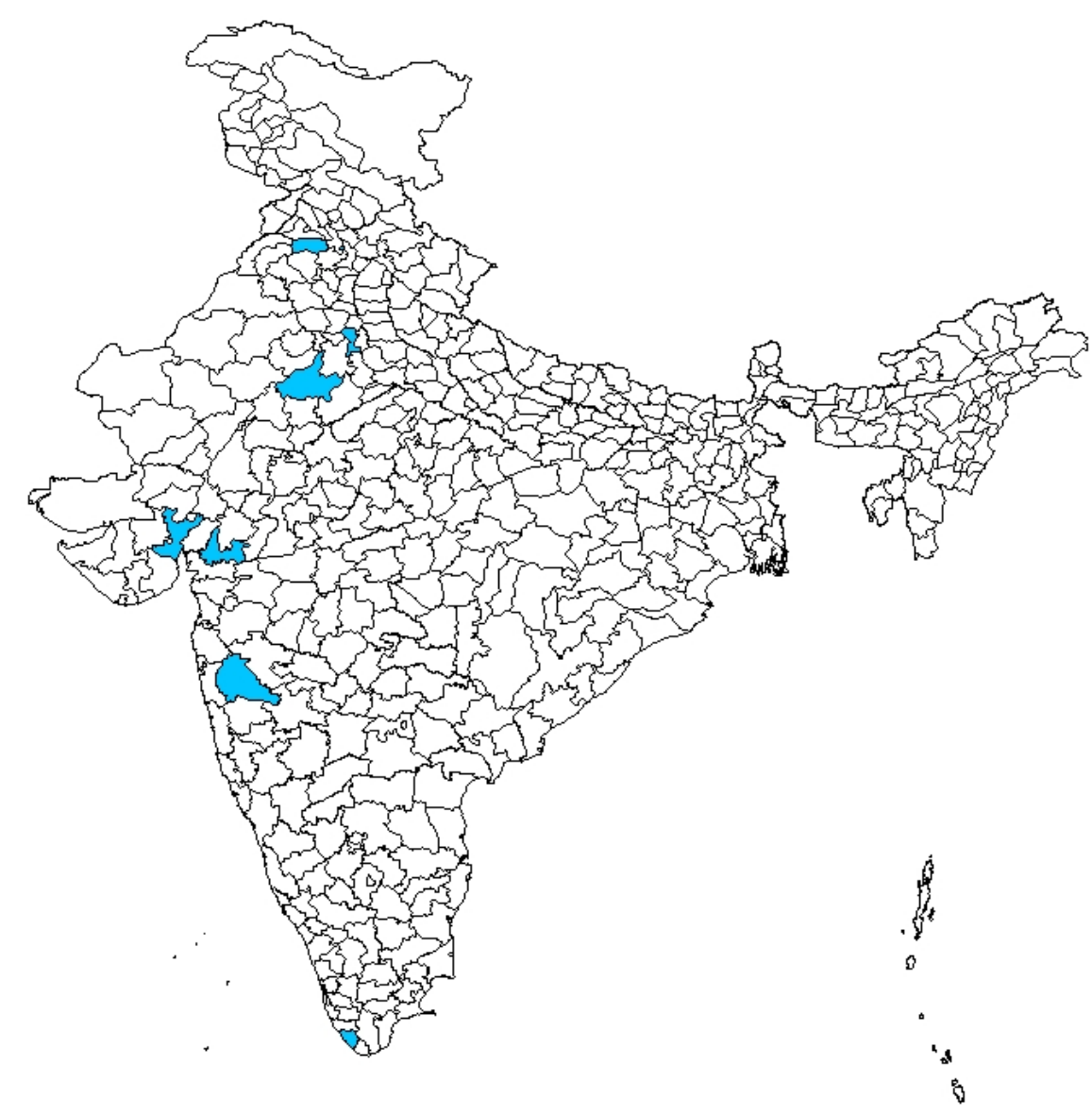

Figure 1 - Indian Districts with First Foreign Bank Entry between 1994-2002 


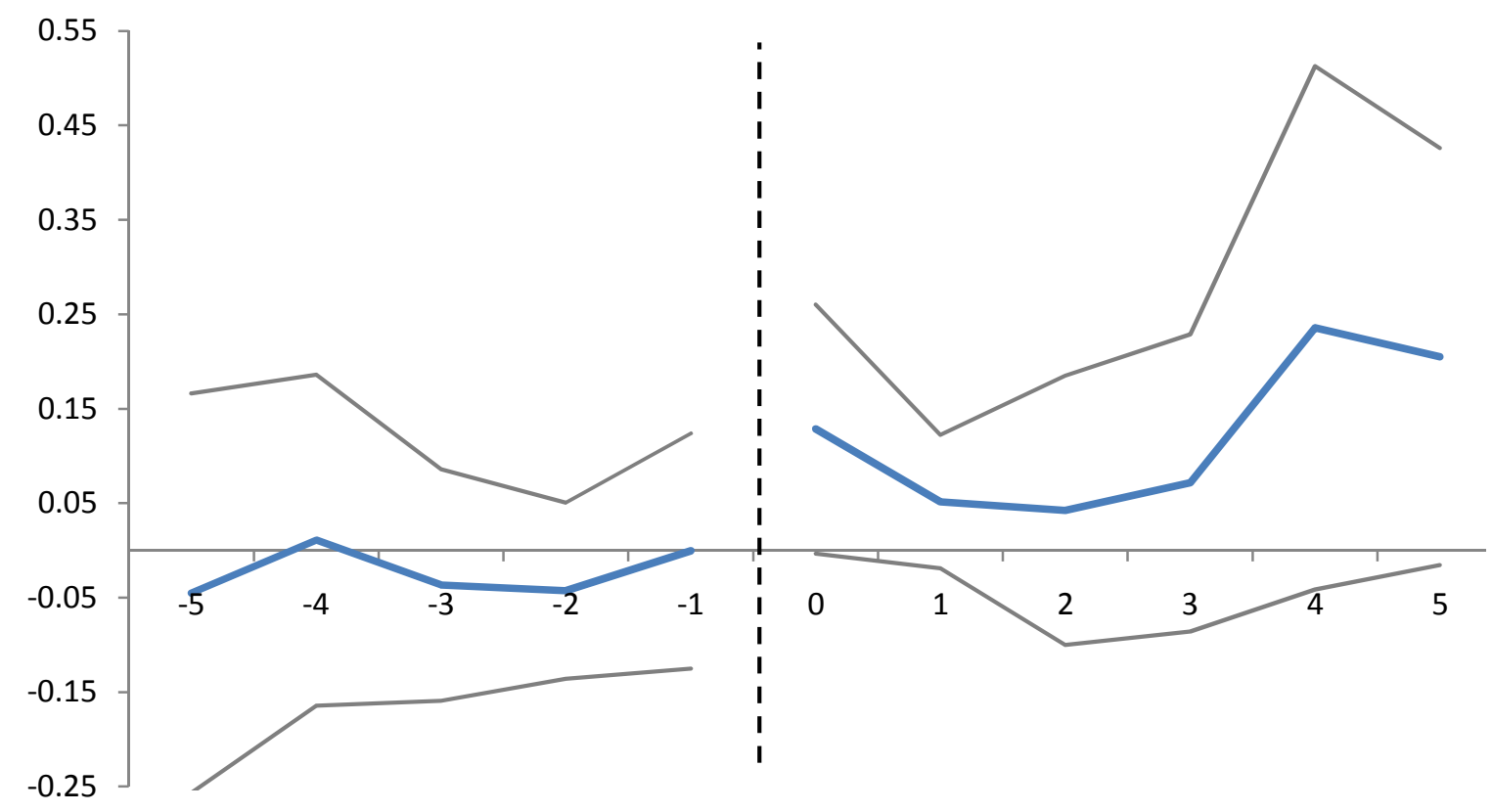

Figure 2 -- Effect of foreign bank entry on timely loss recognition by year

This figure reports the point estimates for $B A N K^{*} D C F O * C F O$ from a firm-level, fixed effects OLS estimate of accruals onto operating cash flows, foreign bank indicators, firm and year fixed effects, and additional time-varying controls and year interactions. The specification is the same as that reported in Table 4 except that the effect of foreign bank entry, i.e.

$B A N K^{*} D C F O^{*} C F O$, is allowed to vary by year. The model is fully saturated and point estimates are reported for five years before and after foreign bank entry. Ninety-five percent confidence intervals, adjusted for clustering at the district level, are also plotted. 
Table 1

Number of Foreign Bank Branches in India by District and Year

\begin{tabular}{|c|c|c|c|c|c|c|c|c|c|c|c|c|c|c|}
\hline District Name & State Name & 1990 & 1991 & 1992 & 1993 & 1994 & 1995 & 1996 & 1997 & 1998 & 1999 & 2000 & 2001 & 2002 \\
\hline \multicolumn{15}{|c|}{ Districts with Pre-Existing Foreign Bank Branches } \\
\hline Amritsar & Punjab & 3 & 3 & 3 & 3 & 3 & 3 & 3 & 3 & 3 & 2 & 1 & 1 & 1 \\
\hline Bangalore Urban & Karnataka & 2 & 2 & 2 & 3 & 3 & 5 & 6 & 7 & 7 & 10 & 11 & 11 & 12 \\
\hline Coimbatore & Tamil Nadu & 1 & 1 & 1 & 1 & 1 & 1 & 1 & 1 & 2 & 2 & 2 & 3 & 4 \\
\hline Darjiling & West Bengal & 1 & 1 & 1 & 1 & 1 & 1 & 1 & 1 & 1 & 1 & 1 & 1 & 1 \\
\hline Delhi & Delhi & 22 & 23 & 24 & 24 & 26 & 28 & 28 & 31 & 35 & 36 & 37 & 38 & 37 \\
\hline Ernakulam & Kerala & 3 & 3 & 3 & 3 & 4 & 4 & 4 & 4 & 4 & 3 & 3 & 3 & 4 \\
\hline Greater Mumbai & Maharashtra & 51 & 52 & 52 & 51 & 51 & 55 & 58 & 63 & 65 & 63 & 64 & 64 & 63 \\
\hline Howrah & West Bengal & 2 & 2 & 2 & 2 & 2 & 2 & 2 & 2 & 2 & 2 & 2 & 2 & 2 \\
\hline Hyderabad & Andhra Pradesh & 1 & 1 & 1 & 1 & 1 & 2 & 2 & 2 & 2 & 4 & 6 & 8 & 8 \\
\hline Kamrup & Assam & 1 & 1 & 1 & 1 & 1 & 1 & 1 & 1 & 1 & 1 & 1 & 1 & 1 \\
\hline Kanpur City & Uttar Pradesh & 3 & 3 & 3 & 3 & 3 & 3 & 3 & 3 & 3 & 3 & 3 & 3 & 3 \\
\hline Kolkata & West Bengal & 43 & 43 & 42 & 42 & 42 & 42 & 42 & 43 & 43 & 34 & 34 & 34 & 34 \\
\hline Kozhikode & Kerala & 1 & 1 & 1 & 1 & 1 & 1 & 1 & 1 & 1 & 1 & & & \\
\hline Chennai & Tamil Nadu & 11 & 11 & 11 & 12 & 12 & 12 & 14 & 15 & 16 & 16 & 16 & 16 & 16 \\
\hline Simla & Himachal Pradesh & 1 & 1 & 1 & 1 & 1 & 1 & 1 & 1 & 1 & 1 & 1 & 1 & 1 \\
\hline South Goa & Goa & 1 & 1 & 1 & 1 & 1 & 1 & 1 & 1 & 1 & 1 & & & \\
\hline Srinagar & Jammu \& Kashmir & 1 & 1 & 1 & 1 & 1 & 1 & 1 & 1 & 1 & 1 & 1 & 1 & 1 \\
\hline Vishakhapatnam & Andhra Pradesh & 1 & 1 & 1 & 1 & 1 & 1 & 1 & 1 & 1 & 1 & 1 & 1 & 1 \\
\hline \multicolumn{15}{|c|}{ Districts Receiving First Foreign Bank } \\
\hline Thiruvananthapuram & Kerala & & & & & 1 & 1 & 1 & 1 & 1 & 1 & 1 & 1 & 1 \\
\hline Ahmedabad & Gujarat & & & & & & 2 & 2 & 3 & 3 & 5 & 5 & 8 & 8 \\
\hline Pune & Maharashtra & & & & & & & 1 & 1 & 4 & 5 & 5 & 5 & 6 \\
\hline Chandigarh & Chandigarh & & & & & & & & 1 & 1 & 1 & 1 & 2 & 2 \\
\hline Gurgaon & Haryana & & & & & & & & & & 1 & 1 & 1 & 2 \\
\hline Vadodara & Gujarat & & & & & & & & & & 1 & 1 & 2 & 2 \\
\hline Jaipur & Rajasthan & & & & & & & & & & & & 1 & 1 \\
\hline Ludhiana & Punjab & & & & & & & & & & & & 1 & 1 \\
\hline Total Foreign Bank & anches & 149 & 151 & 151 & 152 & 156 & 167 & 174 & 187 & 198 & 196 & 198 & 209 & 212 \\
\hline
\end{tabular}

Notes: Number of foreign bank branches calculated using the Directory of Bank Offices . Bank numbers represent total branches as of March 31 each year. 


\section{Table 2}

\section{Summary statistics}

This table provides summary statistics for the samples used in the study. Data is obtained from Prowess data set complied by the Center for Monitoring Indian Economy (CMIE). ACC is accruals computed as $[(\Delta C A-\Delta$ Cash $)-(\Delta C L-\triangle S T D)-D E P]$ scaled by total assets, where $\Delta C A$ is the change in non-cash current assets, $\triangle$ Cash is the change in cash and bank balance, $\triangle C L$ is the change in current liabilities, $\triangle S T D$ is the change in short term debt, and $D E P$ is depreciation expense. $C F O$ is operating cash flows (scaled by total assets), measured as the difference between $R O A$ and $A C C$, where $R O A$ is the profit after tax charges $(P A T)$ scaled by total assets. Debt is measured using total borrowings from banks.

\begin{tabular}{|c|c|c|c|c|c|}
\hline & Mean & Std Dev & $\begin{array}{c}\text { Lower } \\
\text { Quartile }\end{array}$ & Median & $\begin{array}{c}\text { Upper } \\
\text { Quartile }\end{array}$ \\
\hline & \multicolumn{5}{|c|}{ Panel A: Full Sample $(N=20,434)$} \\
\hline ROA & -0.004 & 0.104 & -0.013 & 0.012 & 0.041 \\
\hline ACC/Assets & -0.005 & 0.198 & -0.074 & 0.000 & 0.059 \\
\hline CFO/Assets & 0.000 & 0.186 & -0.053 & 0.000 & 0.064 \\
\hline Total Assets (10 mn. Rp) & 250.167 & 1282.002 & 11.448 & 31.978 & 107.956 \\
\hline \multirow[t]{2}{*}{ Debt/Assets } & 0.167 & 0.330 & 0.039 & 0.127 & 0.225 \\
\hline & \multicolumn{5}{|c|}{ Panel B: Districts where foreign bank entry occurs $(N=6,259)$} \\
\hline ROA & 0.002 & 0.097 & -0.005 & 0.013 & 0.045 \\
\hline ACC/Assets & 0.001 & 0.204 & -0.066 & 0.000 & 0.064 \\
\hline CFO/Assets & -0.002 & 0.195 & -0.053 & 0.000 & 0.065 \\
\hline Total Assets (10 mn. Rp) & 231.437 & 1583.649 & 9.665 & 28.880 & 100.620 \\
\hline \multirow[t]{2}{*}{ Debt/Assets } & 0.133 & 0.150 & 0.015 & 0.101 & 0.191 \\
\hline & \multicolumn{5}{|c|}{ Panel C: Districts with no foreign bank entry $(N=14,175)$} \\
\hline ROA & -0.007 & 0.107 & -0.017 & 0.012 & 0.040 \\
\hline ACC/Assets & -0.008 & 0.195 & -0.077 & 0.000 & 0.056 \\
\hline CFO/Assets & 0.000 & 0.182 & -0.053 & 0.000 & 0.064 \\
\hline Total Assets (10 mn. Rp) & 258.437 & 1123.286 & 12.242 & 33.101 & 111.387 \\
\hline Debt/Assets & 0.182 & 0.383 & 0.050 & 0.138 & 0.238 \\
\hline
\end{tabular}


Table 3

Timely loss recognition prior to foreign bank entry

This table shows OLS estimate of accruals onto operating cash flows (CFO), an indicator for whether operating cash flows are negative (DCFO), and the interaction of these two variables (DCFO*CFO) for the years 1988-1993. Firm and year fixed effects are included along with time-varying controls for size, leverage, and sales growth interacted with each of these variables. Accruals are computed as $\left[\left(\Delta C A_{t}-\Delta C a s h_{t}\right)-\left(\Delta C L_{t}-\Delta S T D_{t}\right)-D E P_{t}\right]$ scaled by total assets, where $\triangle C A$ is the change in non-cash current assets, $\triangle C a s h$ is the change in cash and bank balance, $\triangle C L$ is the change in current liabilities, $\triangle S T D$ is the change in short term debt, and $D E P$ is depreciation expense. $C F O$ is operating cash flows (scaled by total assets), measured as the difference between $R O A$ and $A C C$, where $R O A$ is the profit after tax charges $(P A T)$ scaled by total assets. Standard errors are clustered at the district level.

Dependent Variable $=$ Accruals $($ ACC $)$

\begin{tabular}{|c|c|c|c|c|}
\hline \multirow[b]{4}{*}{ DCFO $_{\text {idt }}$} & \multicolumn{2}{|c|}{ Bank Entry District } & \multicolumn{2}{|c|}{ Non-Bank Entry District } \\
\hline & Coeff & t-stat & Coeff & t-stat \\
\hline & \multicolumn{2}{|c|}{ (i) } & \multicolumn{2}{|c|}{ (ii) } \\
\hline & 0.005 & 0.27 & 0.017 & 1.48 \\
\hline $\mathrm{CFO}_{\text {idt }}$ & -1.001 & -26.34 & 0.980 & -26.70 \\
\hline $\mathrm{DCFO}_{\mathrm{idt}} * \mathrm{CFO}_{\mathrm{idt}}$ & -0.042 & -0.83 & -0.011 & -0.18 \\
\hline Firm fixed effects & \multicolumn{2}{|c|}{$\mathrm{X}$} & \multicolumn{2}{|c|}{$\mathrm{X}$} \\
\hline Year fixed effects & \multicolumn{2}{|c|}{$X$} & \multicolumn{2}{|c|}{$\mathrm{X}$} \\
\hline Additional controls & \multicolumn{2}{|c|}{$\mathrm{X}$} & \multicolumn{2}{|c|}{$\mathrm{X}$} \\
\hline Adj-R² (\%) & \multicolumn{2}{|c|}{92.92} & \multicolumn{2}{|c|}{93.52} \\
\hline $\mathrm{N}$ & \multicolumn{2}{|c|}{1,036} & \multicolumn{2}{|c|}{3,972} \\
\hline
\end{tabular}




\section{Table 4}

\section{Foreign bank entry and timely loss recognition}

This table shows a firm-level, fixed effects OLS estimate of accruals onto operating cash flows as done in Table 3, but also includes a control for whether a foreign bank is present in the district, $B A N K$, and the interaction of this variable with operating cash flows ( $C F O$ ), an indicator for negative operating cash flows $(D C F O)$, and the interaction $C F{ }^{*} D C F O$. Year fixed effects along with their interactions with $C F O, D C F O$, and $C F O * D C F O$ are included. Time-varying controls for size, leverage, and sales growth along with their interaction with $C F O, D C F O$, and $C F O{ }^{*} D C F O$ are also included. The regression also includes $D C F O, C F O$, and $D C F O \times C F O$ interactions with an indicator that equals one for the districts that eventually receive a foreign bank. Standard errors are clustered at the district level.

Dependent Variable $=$ Accruals $($ ACC $)$

$\mathrm{DCFO}_{\text {idt }}$

$\mathrm{CFO}_{\text {idt }}$

$\mathrm{DCFO}_{\text {idt }} * \mathrm{CFO}_{\text {idt }}$

BANK $_{\mathrm{dt}}$

$\mathrm{BANK}_{\mathrm{dt}} * \mathrm{DCFO}_{\mathrm{idt}}$

$\mathrm{BANK}_{\mathrm{dt}} * \mathrm{CFO}_{\mathrm{idt}}$

BANK $_{\mathrm{dt}} * \mathrm{DCFO}_{\mathrm{idt}} * \mathrm{CFO}_{\text {idt }}$

Firm fixed effects

Year fixed effects

Additional controls

Adj-R ${ }^{2}$ (\%)

$\mathrm{N}$

\begin{tabular}{cc} 
Coeff & t-stat \\
\hline \hline & (i) \\
\hline-0.015 & -0.93 \\
-0.800 & -7.25 \\
0.129 & 0.76 \\
0.004 & 0.56 \\
0.013 & 1.95 \\
-0.041 & -1.19 \\
$\mathbf{0 . 0 9 7}$ & $\mathbf{2 . 1 2}$
\end{tabular}

X

$\mathrm{X}$

$\mathrm{X}$

79.6

20,434 


\section{Table 5}

\section{Firm size, foreign bank entry, and timely loss recognition}

This table shows OLS estimate of accruals onto operating cash flows, foreign bank indicators, firm and year fixed effects, and additional time-varying controls and year interactions as done in Table 4, but also divides the sample between small and large firms. The estimates for firms with above median assets are reported in column (i), and estimates for firms with below median assets are reported in column (ii) . Standard errors are clustered at the district level.

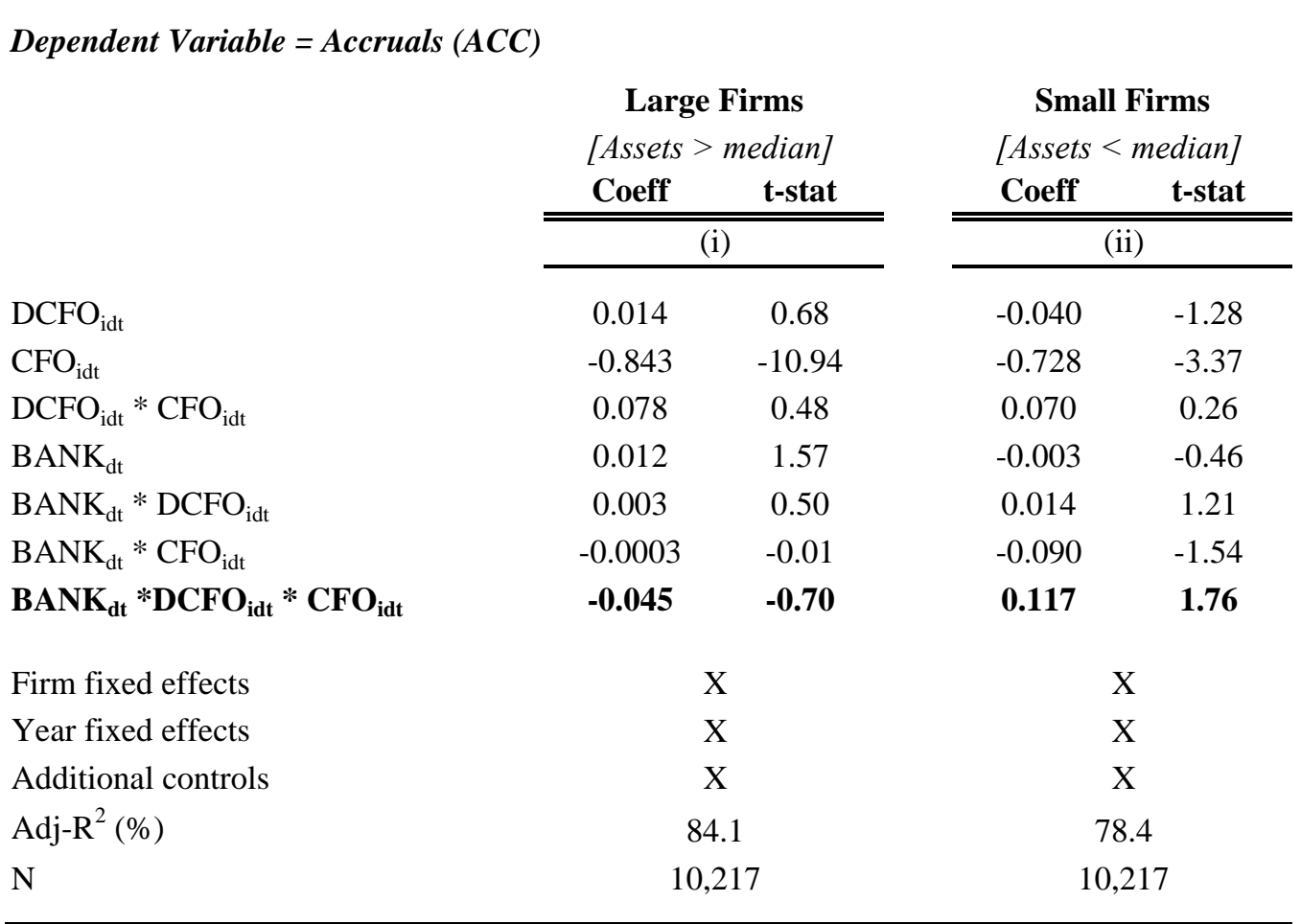




\section{Table 6}

\section{Ownership, foreign bank entry, and timely loss recognition}

This table shows OLS estimate of accruals onto operating cash flows, foreign bank indicators, firm and year fixed effects, and additional time-varying controls and year interactions as done in Table 4, but also divides the sample between public and private firms. The estimates for public firms are reported in column (i), and estimates for private firms are reported in column (ii). Standard errors are clustered at the district level.

Dependent Variable $=$ Accruals $($ ACC)

\begin{tabular}{|c|c|c|c|c|}
\hline \multirow[b]{4}{*}{ DCFO $_{\text {idt }}$} & \multicolumn{2}{|c|}{ Public Firms } & \multicolumn{2}{|c|}{ Private Firms } \\
\hline & Coeff & t-stat & Coeff & t-stat \\
\hline & \multicolumn{2}{|c|}{ (i) } & \multicolumn{2}{|c|}{ (ii) } \\
\hline & -0.003 & -0.14 & 0.039 & 0.92 \\
\hline $\mathrm{CFO}_{\text {idt }}$ & -0.941 & -10.86 & -0.755 & -2.77 \\
\hline $\mathrm{DCFO}_{\text {idt }} * \mathrm{CFO}_{\text {idt }}$ & 0.356 & 1.51 & 0.496 & 1.39 \\
\hline BANK $_{\mathrm{dt}}$ & 0.007 & 0.79 & -0.002 & -0.11 \\
\hline $\mathrm{BANK}_{\mathrm{dt}} * \mathrm{DCFO}_{\mathrm{idt}}$ & 0.010 & 1.03 & 0.021 & 1.56 \\
\hline $\mathrm{BANK}_{\mathrm{dt}} * \mathrm{CFO}_{\mathrm{idt}}$ & -0.074 & -1.16 & -0.104 & -1.35 \\
\hline BANK $_{\mathrm{dt}} * \mathrm{DCFO}_{\mathrm{idt}} * \mathrm{CFO}_{\text {idt }}$ & 0.139 & 1.24 & 0.257 & 1.82 \\
\hline Firm fixed effects & \multicolumn{2}{|c|}{$\mathrm{X}$} & \multicolumn{2}{|c|}{$\mathrm{X}$} \\
\hline Year fixed effects & \multicolumn{2}{|c|}{$\mathrm{X}$} & \multicolumn{2}{|c|}{$\mathrm{X}$} \\
\hline Additional controls & \multicolumn{2}{|c|}{$\mathrm{X}$} & \multicolumn{2}{|c|}{$\mathrm{X}$} \\
\hline $\operatorname{Adj}-R^{2}(\%)$ & \multicolumn{2}{|c|}{76.9} & \multicolumn{2}{|c|}{75.5} \\
\hline $\mathrm{N}$ & \multicolumn{2}{|c|}{9,036} & \multicolumn{2}{|c|}{7,066} \\
\hline
\end{tabular}




\section{Table 7}

\section{Group firm, foreign bank entry, and timely loss recognition}

This table shows OLS estimate of accruals onto operating cash flows, foreign bank indicators, firm and year fixed effects, and additional time-varying controls and year interactions as done in Table 4, but also divides the sample between public and private firms. The estimates for group-affiliated firms are reported in column (i), and estimates for nongroup firms are reported in column (ii). Standard errors are clustered at the district level.

\begin{tabular}{|c|c|c|c|c|}
\hline \multicolumn{5}{|c|}{ Dependent Variable $=$ Accruals $($ ACC $)$} \\
\hline & \multicolumn{2}{|c|}{ Group Firms } & \multicolumn{2}{|c|}{ Non-group Firms } \\
\hline & Coeff & t-stat & Coeff & t-stat \\
\hline & \multicolumn{2}{|c|}{ (i) } & \multicolumn{2}{|c|}{ (ii) } \\
\hline $\mathrm{DCFO}_{\text {idt }}$ & -0.023 & -1.46 & 0.011 & 0.48 \\
\hline $\mathrm{CFO}_{\text {idt }}$ & -0.894 & -10.31 & -0.762 & -4.25 \\
\hline $\mathrm{DCFO}_{\text {idt }} * \mathrm{CFO}_{\text {idt }}$ & -0.037 & -0.27 & 0.357 & 1.50 \\
\hline BANK $_{\mathrm{dt}}$ & 0.014 & 1.82 & -0.005 & -0.53 \\
\hline $\mathrm{BANK}_{\mathrm{dt}} * \mathrm{DCFO}_{\mathrm{idt}}$ & 0.003 & 0.30 & 0.016 & 1.57 \\
\hline $\mathrm{BANK}_{\mathrm{dt}} * \mathrm{CFO}_{\mathrm{idt}}$ & -0.086 & -1.24 & -0.028 & -0.80 \\
\hline BANK $_{\mathrm{dt}} * \mathrm{DCFO}_{\text {idt }} * \mathrm{CFO}_{\mathrm{idt}}$ & 0.067 & 0.89 & 0.114 & 2.16 \\
\hline Firm fixed effects & \multicolumn{2}{|c|}{$\mathrm{X}$} & \multicolumn{2}{|c|}{$\mathrm{X}$} \\
\hline Year fixed effects & \multicolumn{2}{|c|}{$\mathrm{X}$} & \multicolumn{2}{|c|}{$\mathrm{X}$} \\
\hline Additional controls & \multicolumn{2}{|c|}{$\mathrm{X}$} & \multicolumn{2}{|c|}{$\mathrm{X}$} \\
\hline $\operatorname{Adj-R}{ }^{2}(\%)$ & \multicolumn{2}{|c|}{81.7} & \multicolumn{2}{|c|}{79.3} \\
\hline $\mathrm{N}$ & \multicolumn{2}{|c|}{8,062} & \multicolumn{2}{|c|}{12,372} \\
\hline
\end{tabular}


Table 8

External financing depedence, foreign bank entry, and timely loss recognition

This table shows OLS estimate of accruals onto operating cash flows, foreign bank indicators, firm and year fixed effects, and additional timevarying controls and year interactions as done in Table 4, but also divides the sample based on their level of external financing needs. Following Rajan and Zingales (1998), we measure external financing dependence at the industry level for Indian firms using data from U.S. firms. If a firm belongs to an industry that is above median in external financing dependence among all the industries in the sample, we classify it as in high external dependence group, otherwise as in low external dependence group. The estimates for the full sample of firms are reported in columns (i) and (ii), and estimates for private firms are reported in columns (iii) and (iv). Standard errors are clustered at the district level.

\section{Dependent Variable $=$ Accruals $(A C C)$}

\begin{tabular}{|c|c|c|c|c|c|c|c|c|}
\hline & & & & & & Privat & is Only & \\
\hline & High D & dence & Low D & dence & $\operatorname{High} D$ & dence & Low D & dence \\
\hline & Coeff & t-stat & Coeff & t-stat & Coeff & t-stat & Coeff & t-stat \\
\hline & & & & & & & & \\
\hline $\mathrm{DCFO}_{\text {idt }}$ & 0.030 & 1.08 & -0.064 & -2.77 & 0.064 & 0.81 & -0.037 & -0.70 \\
\hline $\mathrm{CFO}_{\text {idt }}$ & -0.658 & -2.85 & -0.995 & -6.28 & -0.475 & -0.81 & -1.163 & -7.22 \\
\hline $\mathrm{DCFO}_{\text {idt }} * \mathrm{CFO}_{\text {idt }}$ & -0.305 & -1.11 & 0.301 & 1.59 & -0.432 & -0.79 & 0.426 & 1.71 \\
\hline BANK $_{\mathrm{dt}}$ & 0.015 & 1.56 & 0.012 & 1.15 & 0.039 & 1.77 & 0.013 & 0.68 \\
\hline $\mathrm{BANK}_{\mathrm{dt}} * \mathrm{DCFO}_{\text {idt }}$ & 0.015 & 1.56 & -0.004 & -0.30 & 0.022 & 0.85 & 0.011 & 0.50 \\
\hline $\mathrm{BANK}_{\mathrm{dt}} * \mathrm{CFO}_{\text {idt }}$ & -0.059 & -0.66 & -0.025 & -0.76 & -0.248 & -1.67 & -0.052 & -0.57 \\
\hline BANK $_{\mathrm{dt}} * \mathrm{DCFO}_{\mathrm{idt}} * \mathrm{CFO}_{\mathrm{idt}}$ & 0.125 & 1.30 & 0.072 & 0.87 & 0.533 & 3.01 & 0.239 & 1.52 \\
\hline Firm fixed effects & & & & & & & & \\
\hline Year fixed effects & & & & & & & & \\
\hline Additional controls & & & & & & & & \\
\hline $\operatorname{Adj}-R^{2}(\%)$ & & & & & & & & \\
\hline $\mathrm{N}$ & & & & & & & & \\
\hline
\end{tabular}


Table 9

\section{Credit access and timely loss recognition after foreign bank entry}

This table shows OLS estimate of accruals onto operating cash flows, foreign bank indicators, firm and year fixed effects, and additional time-varying controls and year interactions as done in Table 4, but instead restricts the sample to only include observations from districts that experience foreign bank entry during the sample time period. In column (i), estimates for the full sample of firms are presented. Columns (ii) and (iii) divide the sample between firms that experience a decline in total bank loans in the three years after foreign bank entry and those without a decline. The estimates for firms that experience a drop in bank loans are reported in column (ii), and estimates for all other firms are reported in column (iii). Standard errors are clustered at the district level.

\section{Dependent Variable $=$ Accruals $($ ACC)}

\begin{tabular}{|c|c|c|c|c|c|c|}
\hline & \multicolumn{2}{|c|}{$\begin{array}{c}\text { Only Firms in District } \\
\text { with Foreign Entry }\end{array}$} & \multicolumn{2}{|c|}{$\begin{array}{c}\text { Firms with } \\
\text { Debt Reduction }\end{array}$} & \multicolumn{2}{|c|}{$\begin{array}{c}\text { Firms with no } \\
\text { Debt Reduction }\end{array}$} \\
\hline & Coeff & t-stat & Coeff & t-stat & Coeff & t-stat \\
\hline & \multicolumn{2}{|c|}{ (i) } & \multicolumn{2}{|c|}{ (ii) } & \multicolumn{2}{|c|}{ (iii) } \\
\hline $\mathrm{DCFO}_{\text {idt }}$ & -0.027 & -2.09 & -0.027 & -1.06 & -0.016 & -0.64 \\
\hline $\mathrm{CFO}_{\mathrm{idt}}$ & -1.024 & -18.97 & -1.079 & -10.63 & -0.923 & -11.61 \\
\hline $\mathrm{DCFO}_{\mathrm{idt}} * \mathrm{CFO}_{\mathrm{idt}}$ & 0.266 & 1.22 & 0.310 & 2.27 & 0.144 & 0.40 \\
\hline $\mathrm{BANK}_{\mathrm{dt}}$ & 0.000 & -0.02 & 0.001 & 0.11 & 0.011 & 0.95 \\
\hline $\mathrm{BANK}_{\mathrm{dt}} * \mathrm{DCFO}_{\mathrm{idt}}$ & 0.021 & 2.90 & 0.015 & 1.68 & 0.017 & 0.89 \\
\hline $\mathrm{BANK}_{\mathrm{dt}} * \mathrm{CFO}_{\mathrm{idt}}$ & -0.008 & -0.57 & 0.002 & 0.06 & -0.040 & -0.96 \\
\hline $\mathrm{BANK}_{\mathrm{dt}} * \mathrm{DCFO}_{\mathrm{idt}} * \mathrm{CFO}_{\mathrm{idt}}$ & 0.084 & 2.60 & 0.002 & 0.08 & 0.189 & 2.74 \\
\hline Firm fixed effects & \multicolumn{2}{|c|}{$X$} & \multicolumn{2}{|c|}{$\mathrm{X}$} & \multicolumn{2}{|c|}{$\mathrm{X}$} \\
\hline Year fixed effects & \multicolumn{2}{|c|}{$\mathrm{X}$} & \multicolumn{2}{|c|}{$\mathrm{X}$} & \multicolumn{2}{|c|}{$\mathrm{X}$} \\
\hline Additional controls & \multicolumn{2}{|c|}{$\mathrm{X}$} & \multicolumn{2}{|c|}{$\mathrm{X}$} & \multicolumn{2}{|c|}{$\mathrm{X}$} \\
\hline Adj-R ${ }^{2}(\%)$ & \multicolumn{2}{|c|}{85.2} & \multicolumn{2}{|c|}{85.2} & \multicolumn{2}{|c|}{85.7} \\
\hline $\mathrm{N}$ & \multicolumn{2}{|c|}{6,259} & \multicolumn{2}{|c|}{3,298} & \multicolumn{2}{|c|}{2,961} \\
\hline
\end{tabular}


Table 10

Foreign bank entry, write-offs, bad debt expenses, extraordinary expenses, and provisions

This table shows OLS estimates of various accounting ratios regressed onto the foreign bank indicator, firm and year fixed effects, and additional time-varying controls for firms located in districts that experience foreign bank entry during the sample time period. In column (i), the dependent variable is write-offs scaled by average gross fixed assets in years $t$ 1 and $t$; in column (ii), the dependent variable is bad debt expenses scaled by total account receivables; in column (iii), the dependent variable is extraordinary expenses scaled by sales; and in column (iv), the dependent variable is provision for contingencies scaled by average total assets in years $t-1$ and $t$. The additional controls time-varying controls are firm size and sales growth. Standard errors are clustered at the district level.

\begin{tabular}{|c|c|c|c|c|c|c|c|c|}
\hline \multirow[t]{3}{*}{ Dependent Variable = } & \multicolumn{2}{|c|}{$\begin{array}{l}\text { Write-offs / } \\
\text { Average Gross } \\
\text { Fixed Asets }\end{array}$} & \multicolumn{2}{|c|}{$\begin{array}{l}\text { Bad Debt Expenses } \\
\text { / Total Receivables }\end{array}$} & \multicolumn{2}{|c|}{$\begin{array}{c}\text { Extraordinary } \\
\text { Expenses / Sales }\end{array}$} & \multicolumn{2}{|c|}{$\begin{array}{l}\text { Provisions for } \\
\text { Contingencies / } \\
\text { Average Assets }\end{array}$} \\
\hline & Coeff & t-stat & Coeff & t-stat & Coeff & t-stat & Coeff & t-stat \\
\hline & \multicolumn{2}{|c|}{ (i) } & \multicolumn{2}{|c|}{ (ii) } & \multicolumn{2}{|c|}{ (iii) } & \multicolumn{2}{|c|}{ (iv) } \\
\hline BANK $_{\mathrm{dt}}$ & 0.006 & 2.72 & 0.037 & 1.90 & 0.070 & 2.08 & 0.00004 & 1.52 \\
\hline Firm fixed effects & \multicolumn{2}{|c|}{$\mathrm{X}$} & \multicolumn{2}{|c|}{$\mathrm{X}$} & \multicolumn{2}{|c|}{$\mathrm{X}$} & \multicolumn{2}{|c|}{$\mathrm{X}$} \\
\hline Year fixed effects & \multicolumn{2}{|c|}{$\mathrm{X}$} & \multicolumn{2}{|c|}{$\mathrm{X}$} & \multicolumn{2}{|c|}{$\mathrm{X}$} & \multicolumn{2}{|c|}{$\mathrm{X}$} \\
\hline Additional controls & \multicolumn{2}{|c|}{$\mathrm{X}$} & \multicolumn{2}{|c|}{$\mathrm{X}$} & \multicolumn{2}{|c|}{$\mathrm{X}$} & \multicolumn{2}{|c|}{$\mathrm{X}$} \\
\hline Adj-R ${ }^{2}(\%)$ & \multicolumn{2}{|c|}{66.33} & \multicolumn{2}{|c|}{11.44} & \multicolumn{2}{|c|}{9.53} & \multicolumn{2}{|c|}{15.86} \\
\hline $\mathrm{N}$ & \multicolumn{2}{|c|}{6,129} & \multicolumn{2}{|c|}{6,220} & \multicolumn{2}{|c|}{5,901} & \multicolumn{2}{|c|}{6,259} \\
\hline
\end{tabular}




\section{Table 11}

\section{Extent of foreign bank entry and timely loss recognition}

This table shows OLS estimate of accruals onto operating cash flows, foreign bank indicators, firm and year fixed effects, and additional time-varying controls and year interactions as done in Table 4, but separately estimates the impact of foreign bank entry based on the extent of their entry into districts. The estimates for firms located in the four districts with the greatest amount of foreign bank entry by 2002 are reported in column (i), and estimates for firms located in the four districts with the least (but positive) amount of foreign bank entry by 2002 are reported in column (ii) . Standard errors are clustered at the district level.

Dependent Variable $=$ Accruals $($ ACC $)$

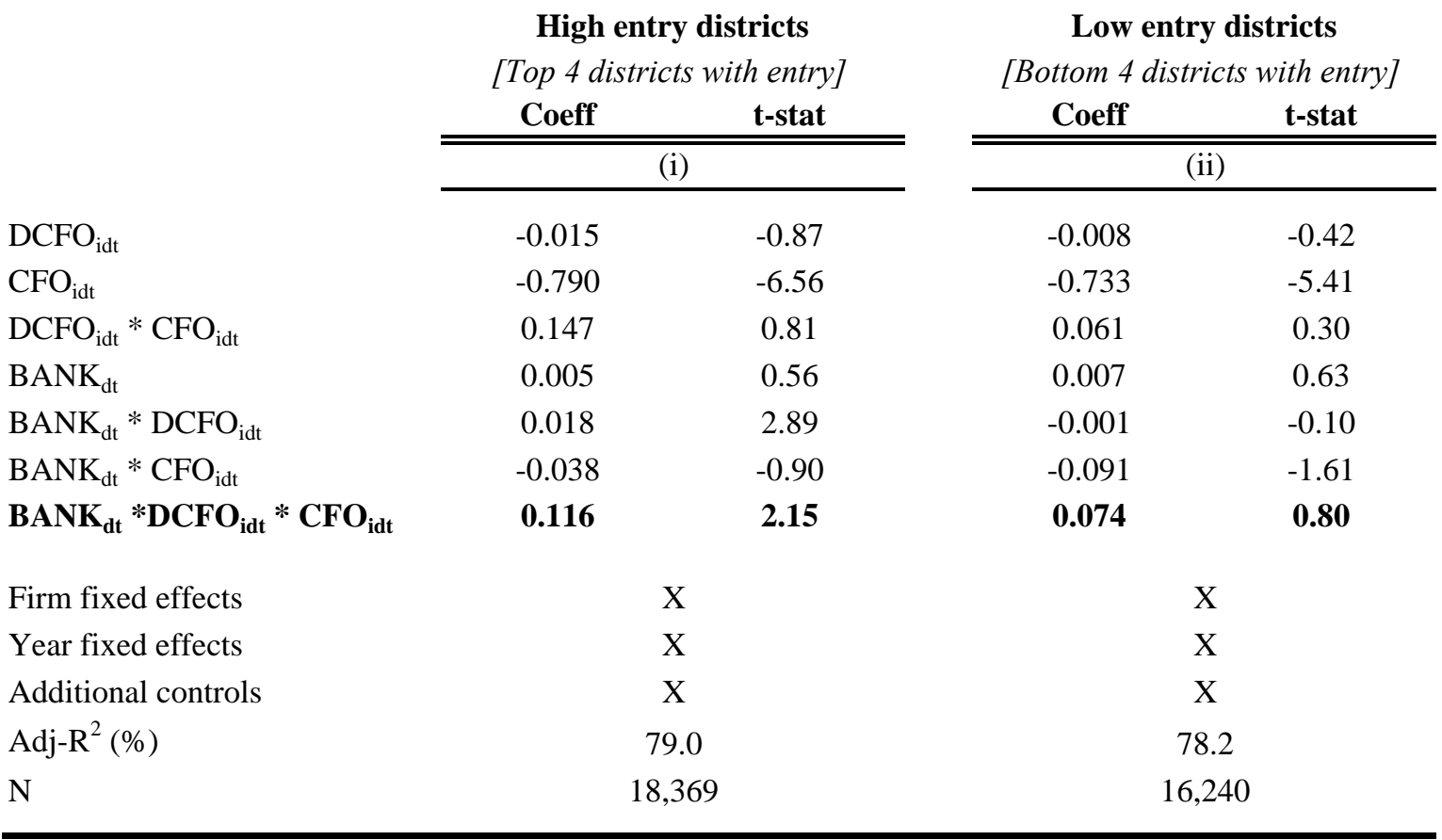




\section{Table 12}

\section{Foreign bank entry and future cash flow predictability}

This table shows the OLS estimates of operating cash flows in year $\mathrm{t}+1\left(\mathrm{CFO}_{t+1}\right)$ onto net income $\left(N I_{t}\right)$, the foreign bank indicator $(B A N K)$ and its interaction with net income $\left(B A N K^{*} N I\right)$, firm and year fixed effects, time-varying controls for size, leverage, and sales growth and their interactions with accruals $\left(A C C_{t}\right)$ and operation cash flows $\left(C F O_{t}\right)$, and interactions of both $C F O$ and $A C C$ with year fixed effects. The base estimates are reported in column (i), and estimates where net income is broken down by operating cash flows and accruals are reported in column (ii) . Standard errors are clustered at the district level.

Dependent Variable $=$ Cash Flows from Operations in Year $t+1\left(\mathrm{CFO}_{t+1}\right)$

\begin{tabular}{|c|c|c|c|}
\hline Coeff & t-stat & Coeff & t-stat \\
\hline \multicolumn{2}{|c|}{ (i) } & \multicolumn{2}{|c|}{ (ii) } \\
\hline 0.095 & 1.32 & & \\
\hline 0.006 & 0.68 & 0.007 & 0.70 \\
\hline \multirow[t]{5}{*}{0.141} & 2.56 & & \\
\hline & & -0.331 & -0.52 \\
\hline & & 0.492 & 1.41 \\
\hline & & 0.196 & 3.02 \\
\hline & & 0.205 & 3.49 \\
\hline \multicolumn{2}{|c|}{$X$} & \multicolumn{2}{|c|}{$\mathrm{X}$} \\
\hline \multicolumn{2}{|c|}{$X$} & \multicolumn{2}{|c|}{$\mathrm{X}$} \\
\hline \multicolumn{2}{|c|}{$\mathrm{X}$} & \multicolumn{2}{|c|}{$\mathrm{X}$} \\
\hline \multicolumn{2}{|c|}{20.15} & \multicolumn{2}{|c|}{25.84} \\
\hline \multicolumn{2}{|c|}{17,887} & \multicolumn{2}{|c|}{17,887} \\
\hline
\end{tabular}




\section{Appendix Table 1 \\ Summary Statistics for Firms Located in Districts with Previous Foreign Bank Entry}

This table provides summary statistics for the observations dropped from the analysis, which are all firms located in districts that already had a foreign bank present prior to 1991. Data is obtained from Prowess data set complied by the Center for Monitoring Indian Economy (CMIE). $A C C$ is accruals computed as [( $\triangle C A-\triangle C a s h)-(\triangle C L-\triangle S T D)-D E P]$ scaled by total assets, where $\Delta C A$ is the change in non-cash current assets, $\triangle$ Cash is the change in cash and bank balance, $\triangle C L$ is the change in current liabilities, $\triangle S T D$ is the change in short term debt, and $D E P$ is depreciation expense. $C F O$ is operating cash flows (scaled by total assets), measured as the difference between $R O A$ and $A C C$, where $R O A$ is the profit after tax charges ( $P A T$ ) scaled by total assets. Debt is measured using total borrowings from banks.

\begin{tabular}{|c|c|c|c|c|c|}
\hline & \multicolumn{5}{|c|}{ Observations in districts with previous foreign bank entry $(N=36,957)$} \\
\hline & Mean & Std Dev & $\begin{array}{c}\text { Lower } \\
\text { Quartile } \\
\end{array}$ & Median & $\begin{array}{c}\text { Upper } \\
\text { Quartile } \\
\end{array}$ \\
\hline ROA & 0.004 & 0.113 & -0.003 & 0.016 & 0.047 \\
\hline ACC/Assets & -0.005 & 0.212 & -0.071 & 0.000 & 0.060 \\
\hline $\mathrm{CFO} /$ Assets & 0.006 & 0.200 & -0.049 & 0.000 & 0.075 \\
\hline Total Assets (10 mn. Rp) & 553.918 & 4929.810 & 10.397 & 30.852 & 110.520 \\
\hline Debt/Assets & 0.157 & 0.762 & 0.005 & 0.103 & 0.207 \\
\hline
\end{tabular}

